\title{
Probable existence of a Gondwana transcontinental rift system in western India: Implications in hydrocarbon exploration in Kutch and Saurashtra offshore: A GIS-based approach
}

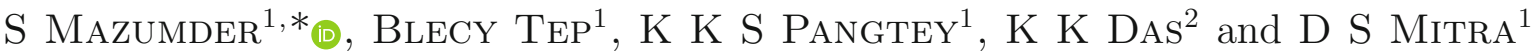 \\ ${ }^{1}$ Remote Sensing and Geomatics, KDMIPE, ONGC, Dehradun 248 195, India. \\ ${ }^{2}$ Sedimentology Division, KDMIPE, ONGC, Dehradun 248 195, India. \\ *Corresponding author. e-mail: subhom007@gmail.com
}

MS received 31 October 2016; revised 21 February 2017; accepted 5 March 2017; published online 31 August 2017

The Gondwanaland assembly rifted dominantly during Late Carboniferous-Early Permian forming several intracratonic rift basins. These rifts were subsequently filled with a thick sequence of continental clastic sediments with minor marine intercalations in early phase. In western part of India, these sediments are recorded in enclaves of Bikaner-Nagaur and Jaisalmer basins in Rajasthan. Facies correlatives of these sediments are observed in a number of basins that were earlier thought to be associated with the western part of India. The present work is a GIS based approach to reconnect those basins to their position during rifting and reconstruct the tectono-sedimentary environment at that time range. The study indicates a rift system spanning from Arabian plate in the north and extending to southern part of Africa that passes through Indus basin, western part of India and Madagascar, and existed from Late Carboniferous to Early Jurassic. Extensions related to the opening of Neo-Tethys led to the formation of a number of cross trends in the rift systems that acted as barriers to marine transgressions from the north as well as disrupted the earlier continuous longitudinal drainage systems. The axis of this rift system is envisaged to pass through present day offshore Kutch and Saurashtra and implies a thick deposit of Late Carboniferous to Early Jurassic sediments in these areas. Based on analogy with other basins associated with this rift system, these sediments may be targeted for hydrocarbon exploration.

Keywords. Permo-Triassic; transcontinental rift system; western India; GIS approach.

\section{Introduction}

During the Late Carboniferous to Lower Jurassic time, the Gondwana assembly of plates underwent major rifting in multiple stages (Langhi and Borel 2005; Metcalfe 2011; Ziegler 2015 and many others). This developed several intracratonic rift basins filled with dominantly continental clastic sediments. Such exposures of Gondwana sediments are found to occur in the central and eastern parts of India, and had been studied in detail (Casshyap 1979; Casshyap and Tewari 1988; Tewari 1998; Bhattacharya et al. 2012; Bhattacharya and Bhattacharya 2015 and many others). In western India, similar correlative deposits occur as outcrops and subcrops in Bikaner-Nagaur and Jaisalmer basins of Rajasthan (figure 1a).

In this study, a GIS based approach is used as a plate reconstruction exercise. This attempts to move and rotate themes representing constituent 
plates of the Gondwana assembly and their inherent structural and stratigraphic elements to their initial position prior to rifting. This forms a novel attempt to reconnect the Late Carboniferous to Early Jurassic sediments of western India with their facies correlatives in terrains of Eastern Africa, Madagascar, Seychelles, Indus Basin and parts of Arabian peninsula of erstwhile associated plates. Based on this correlation, the tectonosedimentary conditions at that time have been reconstructed. During this time, the western part of the Indian plate was associated with SeychellesMadagascar, Africa and Arabian peninsula plates, whereas in the eastern part, it was associated with the Antarctic and Australian plates (figure $1 \mathrm{~b}$, reviewed in Misra and Mukherjee 2015; also see Misra et al. 2014, 2015; Mukherjee 2017). The northern part was a passive margin open towards the Paleo-Tethys at least since Cambrian (Stampfli and Borel 2002) with a number of microcontinents such as Iran, Lut, Lhasa, Karakoram, Sistan-Helmand, Sibumasu positioned across the Paleo-Tethys (Torsvik and Cocks 2013). This plate assembly was positioned in the polar region during Late Carboniferous from where it migrated northward to near equator at the end of Triassic (Scotese et al. 1999, Torsvik and Cocks 2013). At the end of the Pan-African Orogeny in Early Cambrian, all these continents co-existed as Pangaea supercontinent. This plate assembly underwent a general crustal extensional regime in Late Carboniferous and Early Permian producing broadly $\mathrm{N}-\mathrm{S}$ rifts, which, apparently, also preceded the onset of Gondwana's breakup (Delvaux 1991). This paper forms a novel attempt in which, Late Carboniferous to Early Jurassic facies equivalents and associated structural elements in western India and associated plates, as described in existing literature, are analyzed and rotated in a GIS framework to fit their plate tectonic template in the corresponding age. This GIS based exercise helps to bring out new insights into the existing plate tectonic model. The effects and implications of this new model form the principal focus of the study.

\section{Late Carboniferous-Permo-Triassic facies equivalents of associated plates}

A concise account of the tectonic layout and sedimentary succession of Lower Gondwana sediments in contiguous basins during that time period is described as it forms the basic data of the present study. These sedimentary deposits are described in terms of gross lithology and their broad environment of deposition as represented in existing knowledge base. These are then correlated with each other to draw a conclusion about their relationships if any.

\subsection{Karoo deposits of East African basins}

The sediments deposited in Late CarboniferousPermian rifts in the East African countries of South Africa, Kenya, Tanzania and Mozambique are mostly referred to as the Karoo System.

South Africa: In the main Karoo Basin in South Africa (figure 5), the Karoo sequence (figure 2) is subdivided into Dwyka Series (Late Carboniferous), Ecca Series (Early Permian), Beaufort Series (Late Permian-Early Triassic) and Stormberg Series (Late Triassic) (Catuneanu et al. 2005). Among these, the Dwyka Series consists of massive diamictites, varved shales and pebbly sandstones, products of glacial to fluvio-glacial deposition. Studies by Herbert and Compton (2007) indicate that fresh water lake environments also persisted during the deposition of these sediments. The Ecca Series consists of dark clastic sedimentary strata such as shale, siltstones, fine to very coarse, pebbly sandstones and coal. These are inferred as marine to deltaic to fluvio-lacustrine deposits (Uys 2007; Nyathi 2014). The Beaufort Group is terrestrial and consists of lighter coloured mudrocks, sandstones and occasional conglomerates representing predominantly overbank (backswamp and levee splay) fluvial deposition accumulated sub-aerially under oxidizing semi-arid to arid conditions on broad gently subsiding alluvial plains (Smith et al. 1993; Uys 2007). Stromberg series consists mainly of sandstones and mudstones and indicates gradual desertification with westerly wind-dominated sedimentation (Smith et al. 1993).

Tanzania: The Karoo Basin system in Tanzania (figure 5) is a manifestation of the early stage of Gondwana break-up in east-central Africa (Delvaux 2001). The Karoo sequence here is represented by the Songea Group of rocks that range in age from Pennsylvanian to Anisian (lower Middle Triassic) and consists of six formations (figure 3), viz., Idusi, Mchuchuma, Mbuyura, Mhukuru, Ruhuhu, and Usili formations (Wopfner 2002). The lowermost Idusi formation is Late Carboni ferous-Early Permian in age, deposited in a glacial 


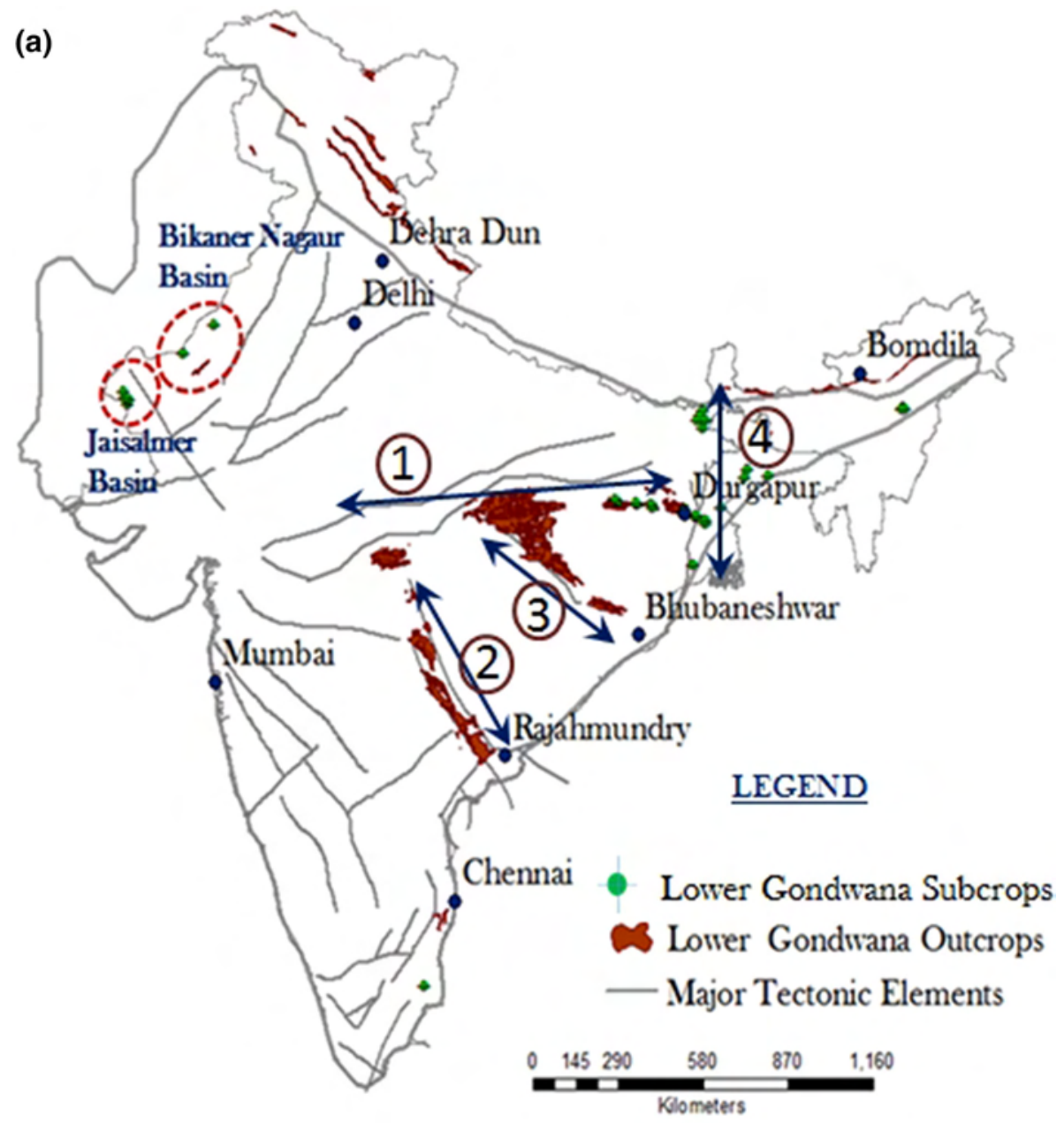

(b)

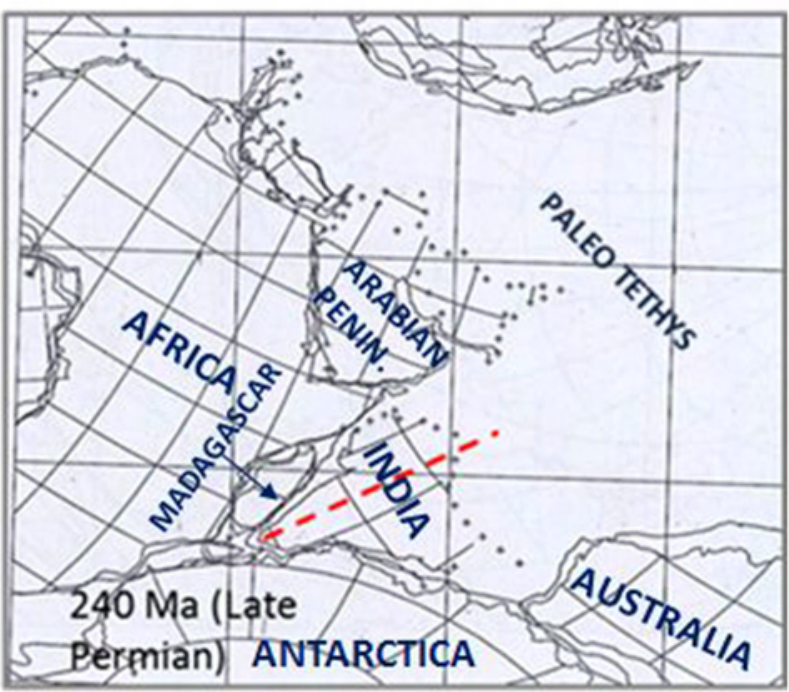

Figure 1. (a) Layout of Lower Gondwana outcrops and subcrops of India along with major tectonic elements. Four major trends of Gondwana rifts in the peninsular area are identified (1) broadly E-W Satpura, Son and Damodar Valley basins, (2) NNW-SSE Pranhita-Godavari Valley basin, (3) NW-SE Mahanadi Valley basin and (4) NNW-SSE trending PurneaRajmahal-Galsi basin (after Mukhopadhyay et al. 2010). The encircled areas show Gondwana outcrops and subcrops in western part of India. (b) Template of Gondwana Plate assemblage associated with the Indian Plate during Late Permian (after Smith et al. 1981). 


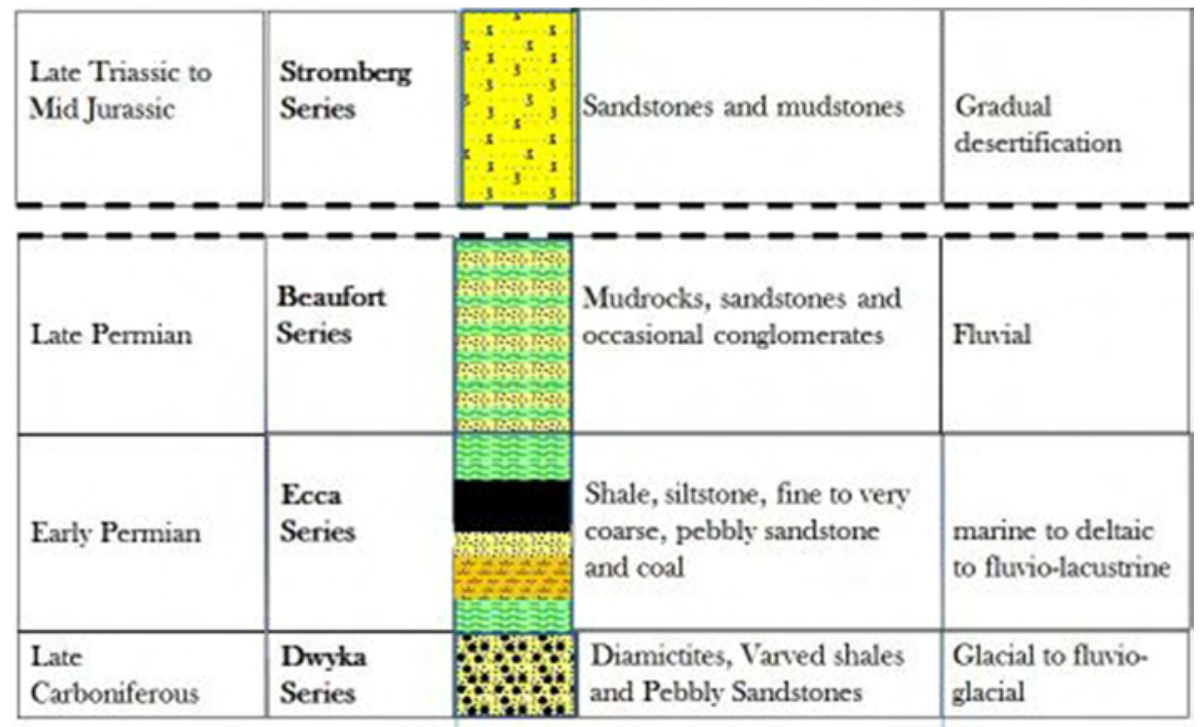

Figure 2. A generalized stratigraphy and depositional environment of main Karoo Basin in South Africa (after Catuneanu et al. 2005). The legends are discussed in figure 11.

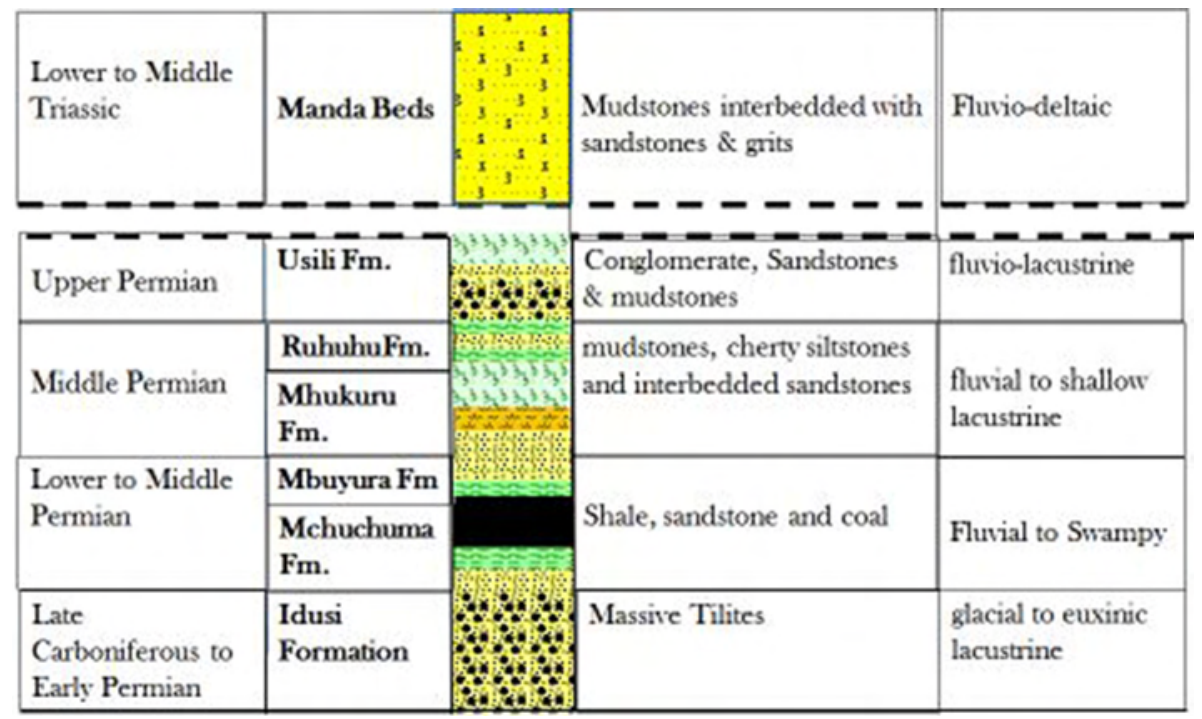

Figure 3. A generalized stratigraphy and depositional environment of Gondwana deposits of Tanzania (after Wopfner 2002).

to euxinic lacustrine environment and composed of massive tillites (Wopfner and Diekmann 1996). The Idusi Formation is followed by a fluvial to swampy coal bearing Mchuchuma Formation (Krueser and Woldu 2010), and Mbuyura Formation of Early to Middle Permian age consisting of sandstones, shales and coal. This is subsequently followed upward by a Middle Permian Mhukuru Formation and Ruhuhu Formation consisting of mudstones, cherty siltstones and interbedded sandstones suggesting fluvial to shallow lacustrine environment (Semkiwa et al. 1998; Wopfner 2002). Further in Late Permian-Early Triassic, the stratigraphy is represented by a fluvio-lacustrine Usili Formation constituted of conglomerates, sandstones and mudstones deposited due to an increased sediment load resulting from subsidence (Sidor et al. 2010). This is followed unconformably upward by desiccating cyclothems of fluvio-deltaic Manda Beds of Early to Middle Triassic (Behrensmeyer and Hill 1988; Wopfner et al. 1991; Wopfner 2002).

Madagascar: In western Madagascar, sediments of the Karoo Supergroup were deposited in the 
(a)

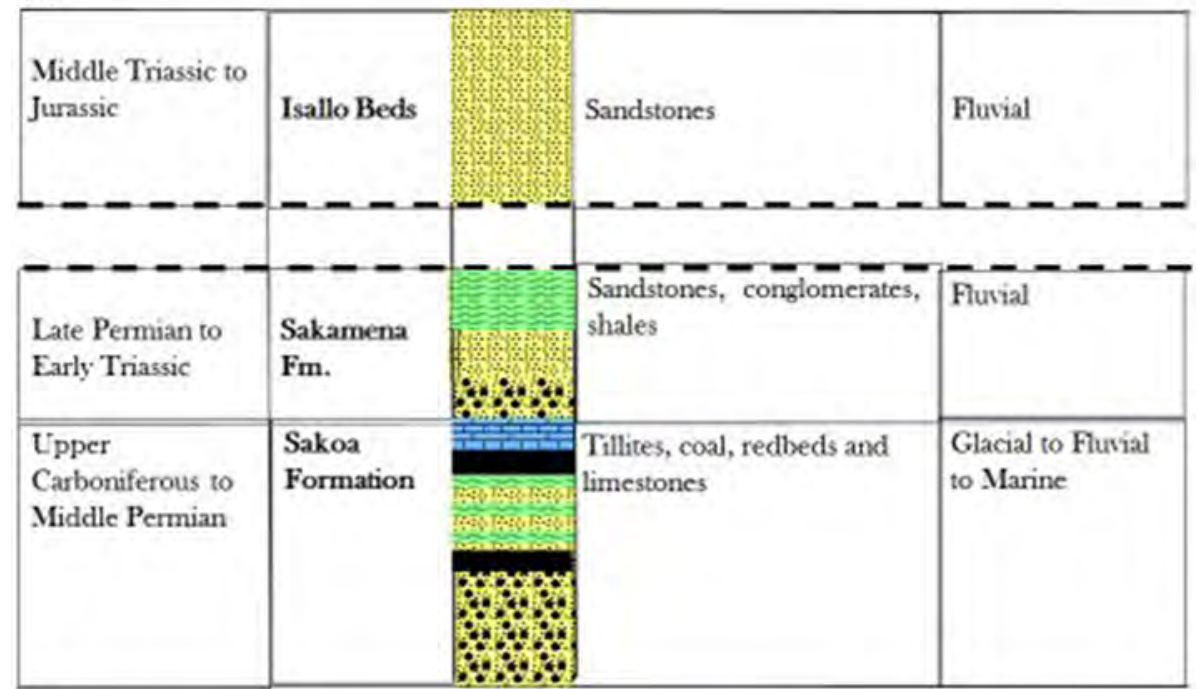

(b)

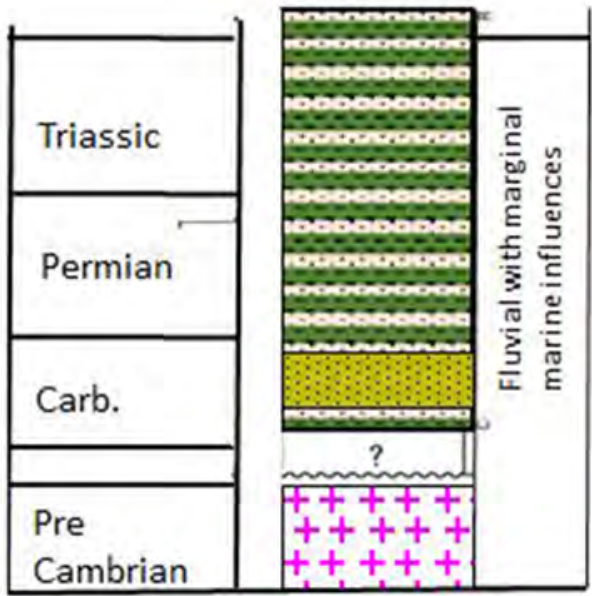

Figure 4. (a) A generalized stratigraphy and depositional environment of Morondova basin of Madagascar (after Schandelmeier et al. 2004). (b) Stratigraphy envisaged in Seychelles after USGS 2012.

Morondova Basin (figure 5). The Sakoa Group are the oldest rocks in the Morondava Basin, consisting of Late Carboniferous-Early Permian tillites, overlain by Early Permian coal-bearing horizons and redbeds, and Middle Permian marine limestones. The Sakamena Group, which unconformably overlies the Sakoa Group, comprises Late Permian sandstones and conglomerates deposited by braided streams followed by Early Triassic alternating sandstones and shales deposited in low gradient meandering streams and in shallow lakes with marine influences. The Middle Triassic to Early Jurassic Lsalo Group (figure 4a) in turn unconformably overlies the Sakamena Group, and consists of continental sandstones deposited by braided streams (Wescott and Diggens 1998; Schandelmeier et al. 2004).
Seychelles: In Seychelles, though only four wells had been drilled with the deepest well Reith Bank-1 penetrating down to Middle Triassic, Late Carboniferous to Permian stratigraphy had also been envisaged (figure 4b), which constituted with shales and sandstones deposited in a fluvial environment with marginal marine influences (after USGS 2012). As per Plummer and Belle (1995) the late Early Jurassic is characterized by a series of cyclical sandstones and shales representing continuing rift sequence deposited by meandering rivers.

Somalia and Ethiopia: In Somalia, the Mugudh Basin or the Somali Embayment shows outcrops of Adigrat Sandstone (figure 5) characterized by three stratigraphic units: a lower sandy conglomerate, middle shale with boulders and upper sandstone believed to be of Early Jurassic age deposited 


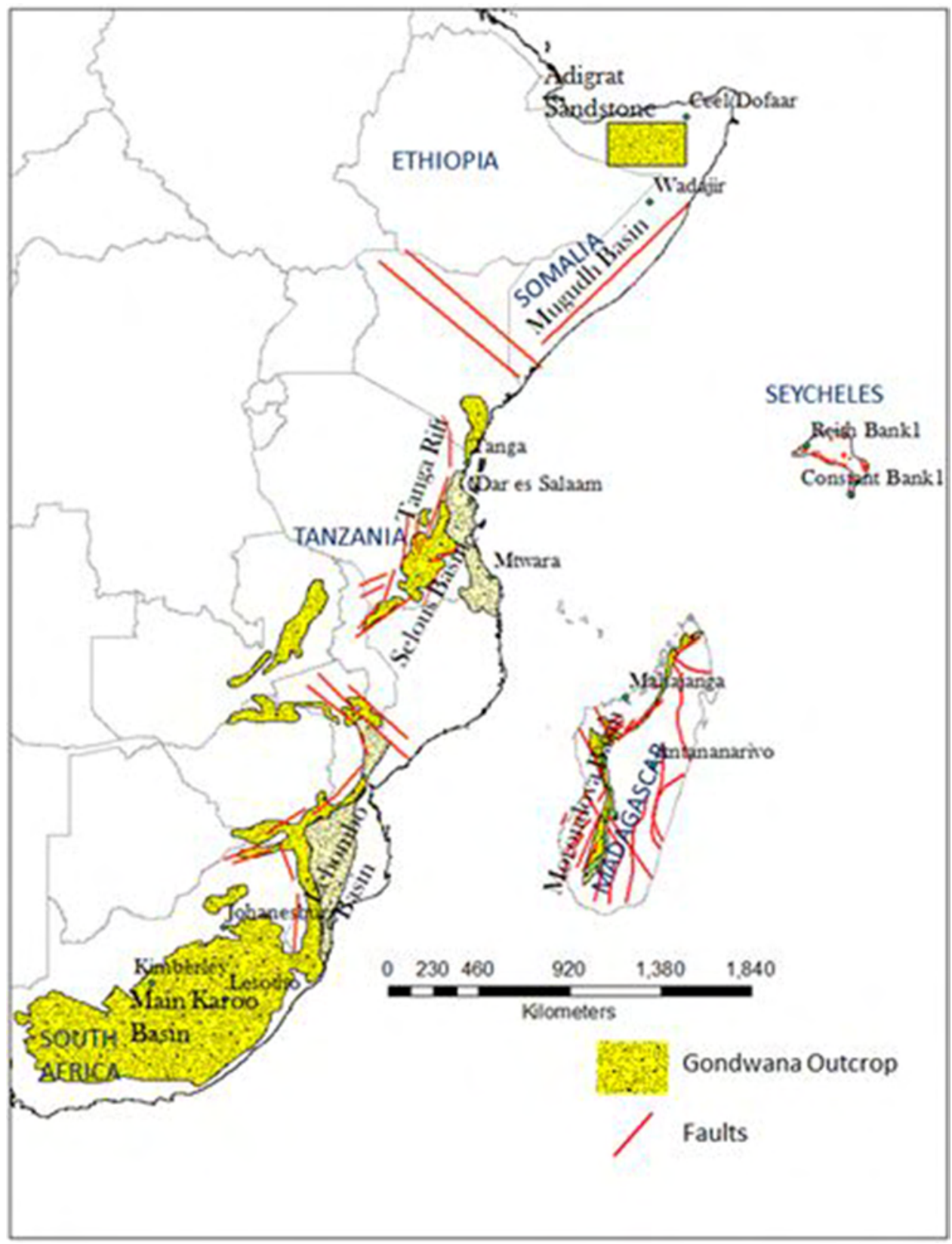

Figure 5. Map depicting the layout of Gondwana formations of the eastern part of African plate, Madagascar and Seychelles along with major structural features (redrawn after Delvaux 1991; Accordi and Carbone 2000; Collins and Windley 2002; Catuneanu et al. 2005; Kumpulainen et al. 2006 and Petroseychelles 2013).

in a fluvial equivalent environment (Selley 1997). In the adjoining Ogaden basin in Ethiopia, the stratigraphic sequences consist of a Late Carboniferous to Early Permian Calub Formation consisting of sandstone and conglomerates deposited in a glacio-fluvial environment. It is followed upward by Middle to Late Permian Bokh Shale consisting of carbonaceous shales deposited in a lacustrine environment. The Bokh Shale is succeeded by a Triassic Gumburo Shale characterized by black shales and sandstones of fluviatile environment, which is overlain by the Adigrat Formation consisting of conglomerates and sandstones deposited in a fluvial environment (Ahmed 2008).

\subsection{Late Carboniferous-Permo-Triassic deposits of eastern Arabian peninsula}

Oman: The Late Carboniferous to Permo-Triassic sediments of the Haushi Group host major hydrocarbon reservoirs in the Oman Interior Basin. This clastic sequence is composed of glacio-fluvial to 
glacio-lacustrine deposits of the Al-Khlata Formation, which consists of a complex package of clastic lithologies that range from conglomerates through diamictites, gravels, pebbly sandstones, siltstones to silty shales (Wang et al. 2011; Heward and Penney 2014). These are overlain by fluvial dominated Gharif Formation (Abbasi et al. 2013) constituted of sandstones and clays deposited by low sinuosity braided streams (figure 6a). Both of these comprise the Haushi Group and are important hydrocarbon reservoirs throughout Oman. This is followed by a Khuff Formation consisting of an alternation of carbonate and siliciclastic deposits resulting from a major marine incursion in the Arabian plate (Al-Aswad 1997; Pollastro 1999). In the Oman Mountain area, which is the margin of the Arabian continental platform, Late Permian to MidCretaceous is represented by Hajar Supergroup constituted predominantly of marine carbonates. The base of this Hajar Supergroup is marked by meter to decameter-thick sequence of Middle Permian clastic and volcanoclastic rocks (Chauvet et al. 2009) associated with pelagic sediments (figure 6b).

\subsection{Late Carboniferous-Permo-Triassic of western part of Indian plate}

In the Indian plate, most of the Gondwana deposits occur in peninsular India. These deposits range in age from Late Carboniferous to Lower Cretaceous and are presently oriented along four major linear belts (figure 1a) namely (1) ENE-WSW trending Satpura and Son Valley basins and E-W to WNWESE trending Damodar-Koel Valley basins (2) NNW-SSE trending Wardha-Pranhita-Godavari Valley basin (3) NW-SE trending Mahanadi Valley basin that swerves to WNW-ESE direction in southernmost Talcher coalfield and (4) NNWSSE trending Purnea-Rajmahal-Galsi basin belt (Mukhopadhyay et al. 2010). Deposition in the Gondwana basin initiated with glaciogenic Talchir Formation followed by coal bearing Karharbari Formation deposited by braided streams and succeeding Barakar Formation by meandering streams in rifted valleys. These coal bearing sequences were followed by a fluvial barren measures characterized with a gap in coal deposition that resumed again in the Late Permian in the form of Raniganj Formation deposited from the meandering streams. In the Early to Middle Triassic (Panchet/Kamthi/ Bhimaram formations), feldspathic sandstone with red beds devoid of coal were deposited by braided streams (Casshyap and Tewari 1988; Veevers and Tewari 1995). Supra-Panchets consisting of coarse grained sandstones and conglomerates were deposited by braided channels in Late Triassic after a renewed phase of fault movement. Deposition ended during an Early Jurassic transpression that dismembered the lobate master basin into individual structural basins (Veevers and Tewari 1995). Equivalent deposits occurring as isolated deposits in the extra-peninsular part of Indian plate in the western extremities are discussed as follows:

Indus Basin: In the Indus Basin, the Late Carboniferous-Permo-Triassic succession is mainly exposed in the Salt Range, Surghar and MarwatKhishor area of Upper Indus Basin; whereas it occurs as subcrops in Middle Indus Basin in Pakistan (figure $7 \mathrm{~b}$ ). This sequence is divided into three groups representing different depositional settings. The largely continental succession is represented by the Nilwahan Group and is the bottommost. The shallow marine Tethyan succession is represented by the overlying Zaluch Group (Jan et al. 2009). This is then succeeded by the Triassic Musa Khel Group with both clastics and carbonates (figure 7a).

In the Nilwahan Group, the oldest deposit is represented by the Early Permian Tobra Formation, glacio-fluvial (Ghazi et al. 2012) in origin consisting of conglomerates, sandstones, siltstones and shales that is considered equivalent to the middle part of the Al Khlata Formation of south Oman (Jan and Stephenson 2011). This is followed upward by Early Permian deposits of Dandot Formation of a marginal marine environment (Ghazi et al. 2012), Warchha Formation of a meandering fluvial origin (Ghazi and Mountney 2010) and Sardhai Formations of a dominantly fluvial origin with lagoonal and marine influences.

The Nilwahan Group is followed upwards by the Zaluch Group consisting of Late Permian Formations of Amb, Wargal and Chhidru (Jan et al. 2009). This Group has well-exposed succession of the shallow marine to inter-tidal carbonate facies of the Amb, Wargal and Chhidru Formations. The Middle Permian Amb Formation is composed of sandy limestones, sandstones, and subordinate pelites of a shallow marine environment (Aadil et al. 2013). This is followed upward by the Wargal Formation, composed of pure limestones with subordinate dolomites and marls indicating carbonate platform in shallow marine reefal environment (Ezaki 2006). The Chhidru Formation shows a 
(a)

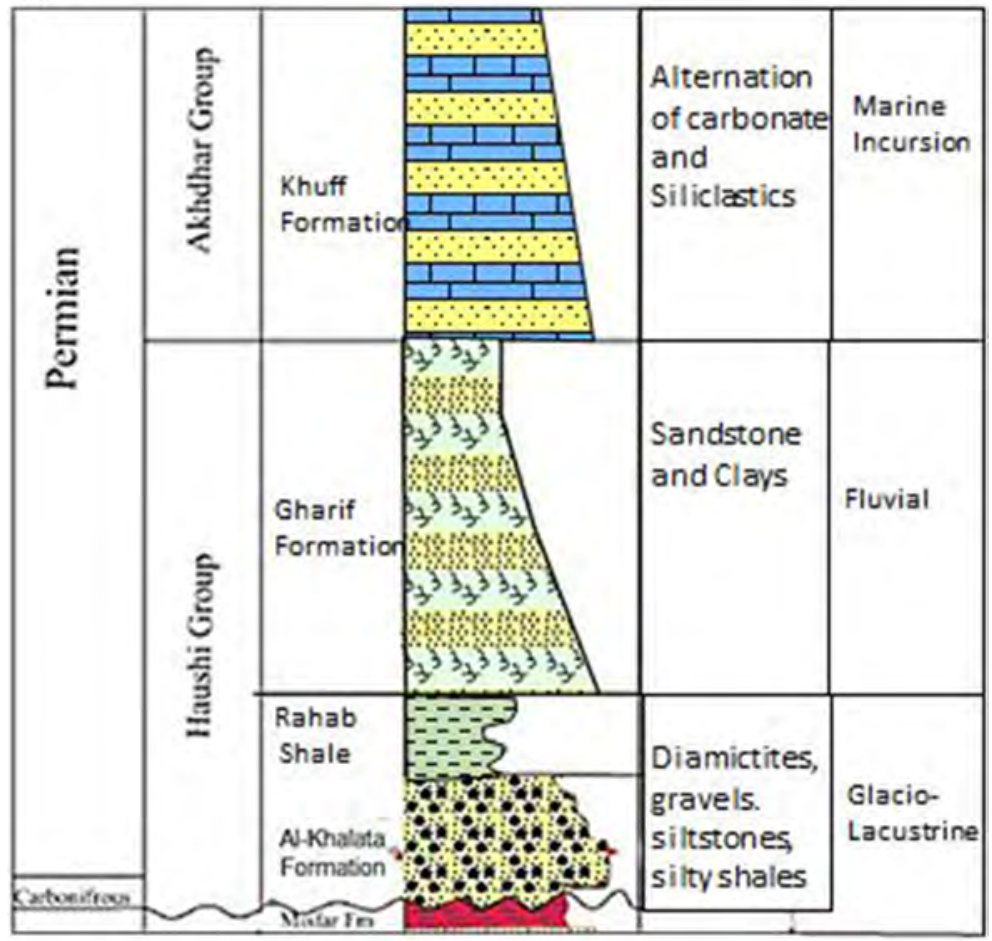

(b)

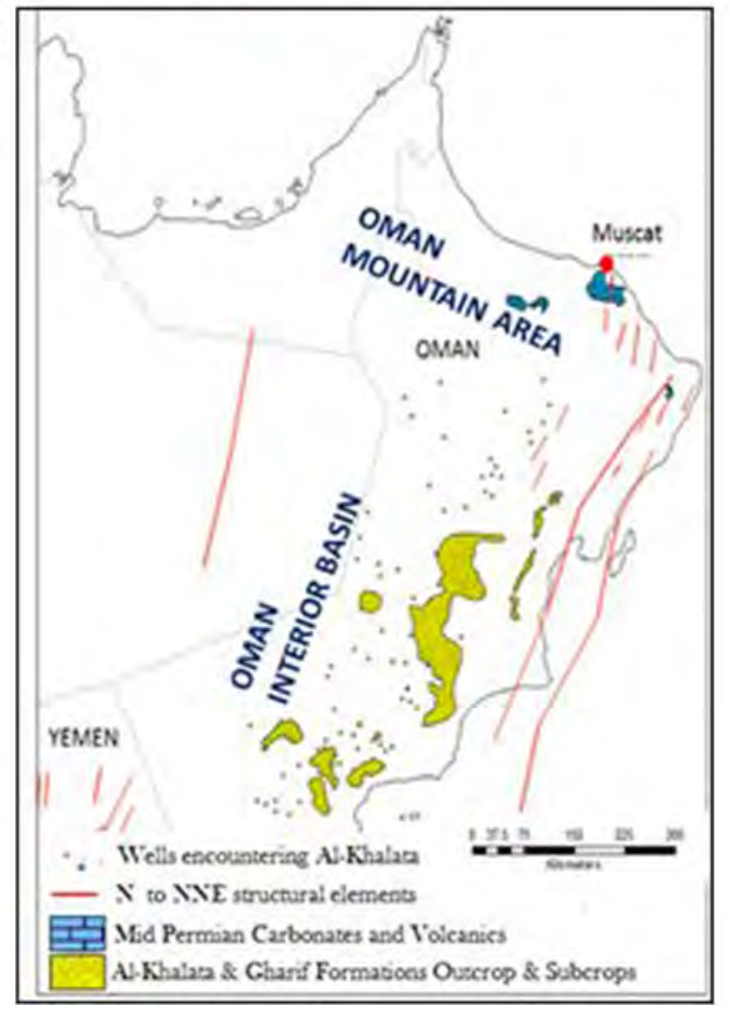

Figure 6. (a) Generalized stratigraphy of Lower Gondwana in Oman (after Abbasi et al. 2013). (b) Map depicting the layout of Gondwana formations in the eastern part of Arabian peninsula, especially Oman along with N-S to NNE-SSW structural features (redrawn after Lapierre et al. 2004; Naji and Janardhana 2009 and Chauvet et al. 2009).

continuous terrigenous input and freshwater inflow (Ezaki 2006) to the basin represented by grey calcareous sandstones, along with in-frequent limestones and shale beds and is considered to be near shore to a sublittoral environment (Khan and Afzal 2005).

This is followed upward by the Triassic Musa Khel Group consisting of Mianwali, Tredian and 


\begin{tabular}{|c|c|c|c|c|c|}
\hline $\begin{array}{l}\text { Lotver Triassic to } \\
\text { Jurassic }\end{array}$ & $\begin{array}{l}\text { Musa Khel } \\
\text { Group }\end{array}$ & $\begin{array}{l}\text { Kingeiali } \\
\text { Tredian } \\
\text { Mianwali }\end{array}$ & & $\begin{array}{l}\text { Dolomites } \\
\text { Micaceous Sandst. } \\
\text { Limestone, Mari }\end{array}$ & $\begin{array}{l}\text { Shallow Marine/ } \\
\text { Shelfal } \\
\text { Fluvial/ Delta } \\
\text { plain } \\
\text { Shallow Marine }\end{array}$ \\
\hline $\begin{array}{l}\text { Middle to Late } \\
\text { Permian }\end{array}$ & $\begin{array}{l}\text { Zaluch } \\
\text { Group }\end{array}$ & $\begin{array}{l}\text { Chhidru } \\
\text { Wargal } \\
\text { Amb }\end{array}$ & 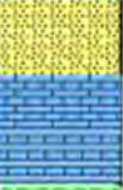 & $\begin{array}{l}\text { Calcareous Sandst. } \\
\text { Pure Limestone } \\
\text { Sandy Limestones }\end{array}$ & $\begin{array}{l}\text { Near-Shore } \\
\text { Reefal } \\
\text { Shallow marine }\end{array}$ \\
\hline Early Permian & $\begin{array}{l}\text { Nilahawann } \\
\text { Group }\end{array}$ & $\begin{array}{l}\text { Sardhai } \\
\text { Warccha } \\
\text { Dandot } \\
\text { Tobra }\end{array}$ & $\frac{x}{* * \alpha x}$ & $\begin{array}{l}\text { Shale } \\
\text { Sandst., Siltstone } \\
\text { Sandstone, Shale } \\
\text { Tillites }\end{array}$ & $\begin{array}{l}\text { Fuvial wich } \\
\text { lagoonal \& marine } \\
\text { Fuvial } \\
\text { Marginal Marine } \\
\text { Glacio-flurial }\end{array}$ \\
\hline
\end{tabular}

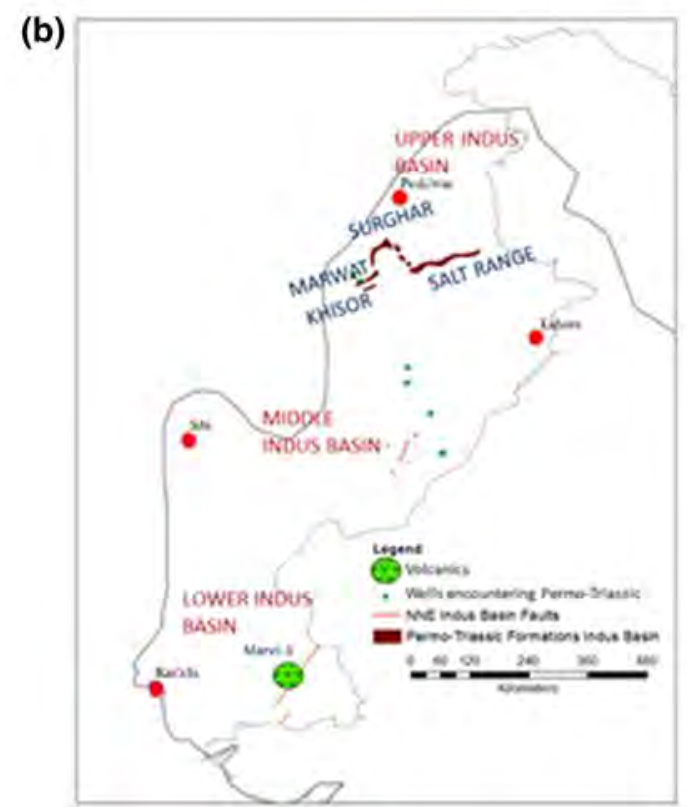

Figure 7. (a) Generalized stratigraphy of Lower Gondwana in Indus Basin (after Khan et al. 1986; Ghazi et al. 2012). (b) Map depicting layout of Permo-Triassic Gondwana formations as outcrops and subcrops in Indus Basin, Pakistan along with structural layout of relevant faults (after Kusky et al. 2005; Raza et al. 2008; Aadil and Sohail 2011; Ghazi et al. 2012; Hasany et al. 2012).

Kingriali Formation. The Mianwali Formation consists of limestones, marls, sandstones, siltstones and dolomites suggesting a shallow marine to pro-delta environment (Iqbal et al. 2013). The overlying Tredian Formation of Middle Triassic is constituted of micaceous sandstones with interbedded shales suggesting a delta plain/fluvial setting with dominant fluvial character (Iqbal et al. 2013). Further upwards the Kingriali Formation of Late Triassic is constituted of dolomitic limestones of a shallow marine origin deposited in shelf conditions (Wandrey et al. 2004). The Kingriali Formation is also referred to as Wulgai Formation occurring as subcrops in Axial belt region of Pakistan (after Ghazi et al. 2012 and Khan et al. 1986). In Well
Marvi-1 in Punjab platform, south Indus Basin, traps with a Permian age had been observed along with Permian sediments (figure 7b).

Bikaner-Nagaur and Jaisalmer Basin: In western India, outcrops of Lower Gondwana age present in Bikaner-Nagaur Basin, Rajasthan are represented by Bap and Badhaura Formation. The Bap Formation is composed of boulder clays with pebbles of rhyolites, granites, limestones and varved clays suggesting a Lower Permian-Carboniferous age and a fluvio-glacial environment with marine influence (Shah and Mehrotra 1985). In the overlying Badhura Formation (figure 8a), the Permian deposits constitute medium-to-coarse grained sandstones with calcareous shales suggesting a shallow 
(a)

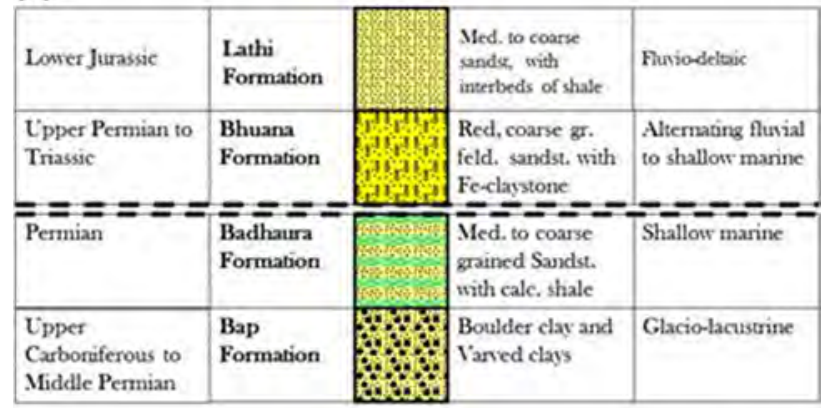

(b)

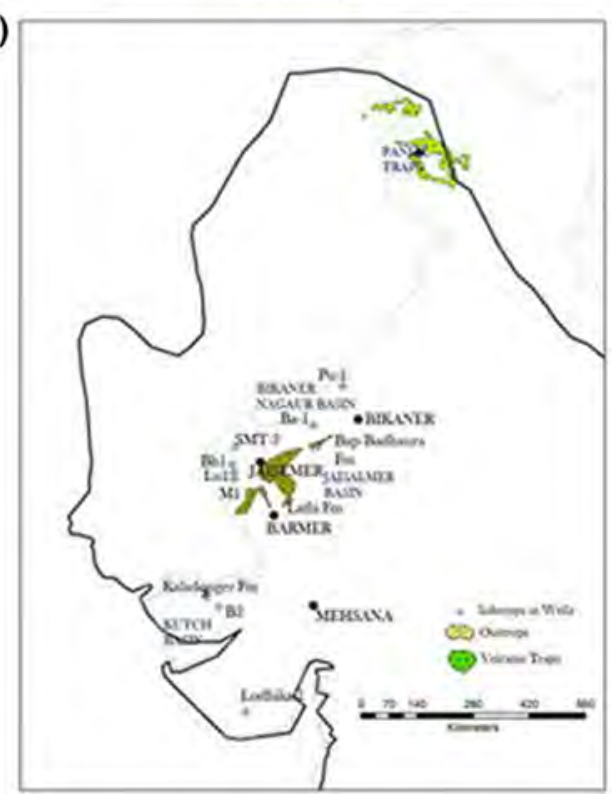

Figure 8. (a) A generalized stratigraphy and depositional environment of Bikaner-Nagaur and Jaisalmer Basins (after Mishra et al. 1961; Lukose and Misra 1980; Shah and Mehrotra 1985; Misra et al. 1996; Singh 2006). (b) Layout of Late Carboniferous-Permian-Triassic-Early Jurassic formations in western India (after Singh 2006; Chauvet et al. 2008; Shellnutt et al. 2012; Raju et al. 2014).

marine environment based on ichnofossil studies by Kulkarni and Bokar (2014). Subcrops of Bap and Badhaura formations are encountered in wells like $\mathrm{Ba}$ drilled by OIL and $\mathrm{Pu}$ by ONGC in Bikaner-Nagaur Basin (figure 8b). An Early Permian (Asselian-Sakamarian) age has been inferred for Bap and Badhaura Formation based on biostratigraphic studies (Venkatachala and Rawat 1984; Prasad et al. 2010).

In the adjacent Jaisalmer Basin, though no outcrops of Permo-Triassic had been mapped, subcrops of Late Permian to Triassic Bhuana Formation had been encountered in a number of wells like Mi-1, Bh-1 and Lu-1 in the Miajlar sub-basin drilled by ONGC (figure 8b). The Bhuana Formation is characterized by reddish, coarse grained, non-calcareous, feldspathic sandstones with intercalations of ferrugeneous claystones (figure 8a; Singh 2006). As per palynostratigraphic studies carried out by Lukose and Misra (1980) and Misra et al. (1996), the lower part of the subcrops is dated Late Permian in age; whereas the upper part are Late Triassic with a hiatus in between. The basal part of the Permian sediments are shallow marine, the upper part of the Permian sequence and basal part of Triassic are non-marine regressive. The sequence immediately overlying the basal part of Triassic is again shallow marine indicating transgression. The top part of it is again non-marine suggesting regression (Singh 2006). The Bhuana Formation is conformably overlain by Lathi Formation comprising of coarse-to-medium grained sandstones with interbeds of shales/claystones and occasional lignite. The thickness of the formation is found to increase in the northern and western part of the basin. Based on biostratigraphic data, Lathi Formation is believed to be of Liassic age deposited in a fluvio-deltaic environment (Singh 2006).

Besides, an outcrop of Panjal volcanics in Kashmir Himalayas (figure 8b) represents a thick sequence of effusive basaltic rocks intercalated with Tethyan sediments with an age of Late Sakmarian of Early Permian (Shellnutt et al. 2012). Undated volcanics of probable Gondwana affinity has also been encountered below Lower Cretaceous formations in ONGC well Lodhika-1 in Saurashtra. Reworked Carboniferous palynomorphs have also been reported from the basal clastic sediments in the Panna Formation (Paleocene-Early Eocene) in Mumbai Offshore (Mehrotra et al. 2001).

\section{Reconstruction and analysis}

All these above facies equivalents of Late Carboniferous-Permo-Triassic in terms of outcrops and subcrops encountered in western India and erstwhile associated plates are plotted in a GIS platform using ArcGIS 10.3. These along with the associated faults are rotated to fit their position in Late Carboniferous-Early Jurassic (figure 9) as per the template described by Smith et al. (1981).

These GIS-based themes of outcrop and subcrops when rotated back to their Late Carboniferous-Early Permian position based on the template described in figure 1(b) display an almost linear disposition of Dwyka Formation of South Africa, Sakoa Formation of Madagascar, subcrops 
Extraction of present day spatial positions of outcrops, subcrops, associated seismic data and major structural elements from existing maps of India, Pakistan, Oman, Madagascar, South Africa, Tanzania, Ethiopia, Somalia and other concerned areas.

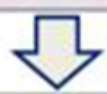

Classification of extracted data based on their time connotations: Late Carboniferous to Early Permian, Middle Permian to Early Triassic and Middle Triassic to Early Jurassic

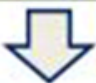

GIS based rotation of the data to fit their template during Late Carb.-Early Jurassic as described by Smith et al, (1981)

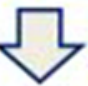

Integration and Analysis of the data in 3 time levels: Late Carboniferous to Early Permian, Middle Permian to Early Triassic and Middle Triassic to Early Jurassic

Figure 9. Flowchart depicting methodology followed in the GIS-based reconstruction.

of Nilahwann Group in Indus basin and the AlKhalata and Gharif formations in Oman for about $6500 \mathrm{~km}$ (figure 10a). Almost in all these deposits, the basal sediments are glacial debris-flows. The faults associated with these deposits also exhibit a parallel trend to these formations and display an apparent continuity. One of the possibilities arising out of these above GIS-based observations involving continuity and similarity in the structural and lithological settings of Gondwana sediments is the probable existence of an embryonic rift that spanned from the end of South Africa through Madagascar, Saurashtra, Kutch, Rajasthan in India, Indus Basin in Pakistan up to the Arabian peninsula in the north. Since the axis of the rift houses the oldest sediments, Late Carboniferous-Early Permian sediments may be expected to occur along the proposed rift axis passing through Saurashtra offshore. These Carboniferous sediments supposedly aligned along the rift axis may serve as source to the reworked Carboniferous palynomorphs in adjacent Mumbai offshore where no Gondwana sediments have been encountered till date. Tectonic upheaval during Seychelles-India separation in Upper Cretaceous may have resulted in the derivation of the palynomorphs from the initial Carboniferous sediments of the rift and their subsequent re-deposition in Paleocene-Early Eocene sediments of Panna Formation. As such, these palynomorphs strengthen the possibility of occurrence of the transcontinental rift. A few of the Carboniferous palynomorphs extracted from the Panna Formation resemble those encountered in the Late Carboniferous-Early Permian Haushi Group in Oman and Dwyka Group in Zimbabwe (Kumar 2010). This suggests a similarity in tectono-sedimentary environment in these three areas. One of the inferences of this observation is that these three areas may be connected through the proposed transcontinental rift at that time that spanned from northern Oman through offshore Kutch and Saurashtra Basin to the south of Africa. In such a case, this paleo-rift also forms the channel for transgression from Paleo-Tethys in the north to the southern part resulting in marine influences in Early Permian formations of Africa and Madagascar. This rift probably breached the tectonic barrier that limited the Cambrian Formations of the Arabian plate and western part of the Indian plate to the north (Pangtey et al. 2013). Permian volcanism encountered in well Marvi-1 in Lower Indus basin has been associated with the Thar Rift that has a parallel disposition to the transcontinental rift trend and is believed to have initiated during initial Gondwana rifting (Zaigham et al. 2012). Undated volcanics occurring non-conformably below the Early Cretaceous Formations are also encountered in well Lodhika-1 in Saurashtra falling in the rift trend (figure 10a). These volcanics may be a result of the plume activity that initiated the transcontinental rift in Late Carboniferous-Early Permian (figure 8b).

In the Middle Permian-Early Triassic, a GISbased tectonic fit indicated that the transcontinental rift widened with its axis migrating westward (figure 10b). The most significant tectonic event in this phase was the opening of Neotethys Ocean, north of Indian plate (Torsvik and Cocks 2013). Thus, a string of Cimmerian terranes moved away from the previous Gondwana craton (Torsvik and Cocks 2013). This separation of the Cimmerian continents and the opening of the Neo-Tethys resulted in an NW-SE axis of extension north of Indian Plate at that time. This extension may be instrumental in the formation of a number of cross trends parallel to the extension axis, transverse to the transcontinental rift trend. One of the 
(a)

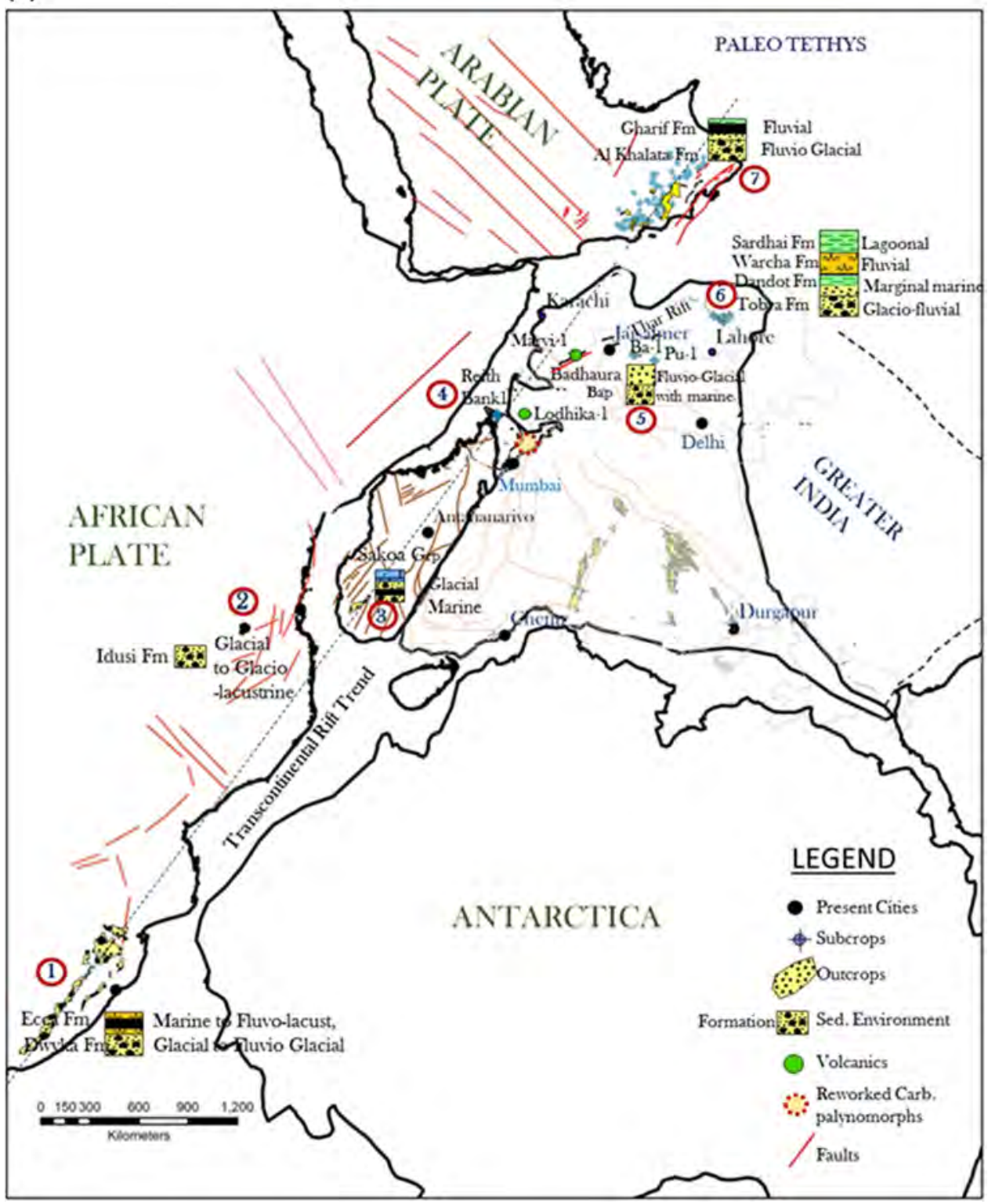

Figure 10. (a) A GIS-based reconstruction of Late Carboniferous-Early Permian facies correlatives and associated faults using template by Smith et al. (1981) shows an overall alignment of outcrops, subcrops and structural feature. This alignment defines the incipient transcontinental rift. The reworked Carboniferous palynomorphs in Panna Formation, Mumbai High may be derived from the adjacent initial transcontinental rift sediments that had been exhumed during the tectonic upheaval leading to the Late Cretaceous separation of Seychelles. In the figure, 1. Main Karoo Basin, 2. Tanzania, 3. Morondova Basin, Madagascar, 4. Seychelles, 5. Bikaner-Nagaur Basin, 6. Indus Basin, 7. Oman. (b) A GIS-based reconstruction of Middle Permian-Early Triassic facies correlatives and associated faults indicate the rift getting-wider in this phase. Structure contours at the base of Triassic (in inset) in Punjab platform, Indus Basin, Pakistan (after Raza et al. 2008) are found to be parallel to rift trend with evidences of development of cross trend in response to opening of Neotethys. The area marked with red dotted line is shown inset with structure contours. In the figure 1. Main Karoo Basin, 2. Tanzania, 3. Morondova Basin, Madagascar, 4. Jaisalmer Basin, India, 5. Indus Basin, Pakistan and 6. Oman. (c) GIS based reconstruction of Middle Triassic to Early Jurassic facies correlatives indicating a dominant fluvial system in the central part of the transcontinental rift spanning Jaisalmer, Kutch basin and Seychelles. Structure contour maps (Raza et al. 2008) in Punjab platform, Indus Basin and faults mapped on base of Jurassic sequence from seismic data in Kutch offshore (Dash et al. 2015) and Jaisalmer Basin are found to follow the rift trend. Litholological symbols described in figure 11.

cross trends may be the Lahore-Sargodha-Delhi basement ridge in northern Indus basin that was uplifted in Middle Permian (Asim et al. 2014).
This ridge may be instrumental in stopping marine incursion from the north resulting in a dominance of carbonate facies north of this ridge whereas 
(b)

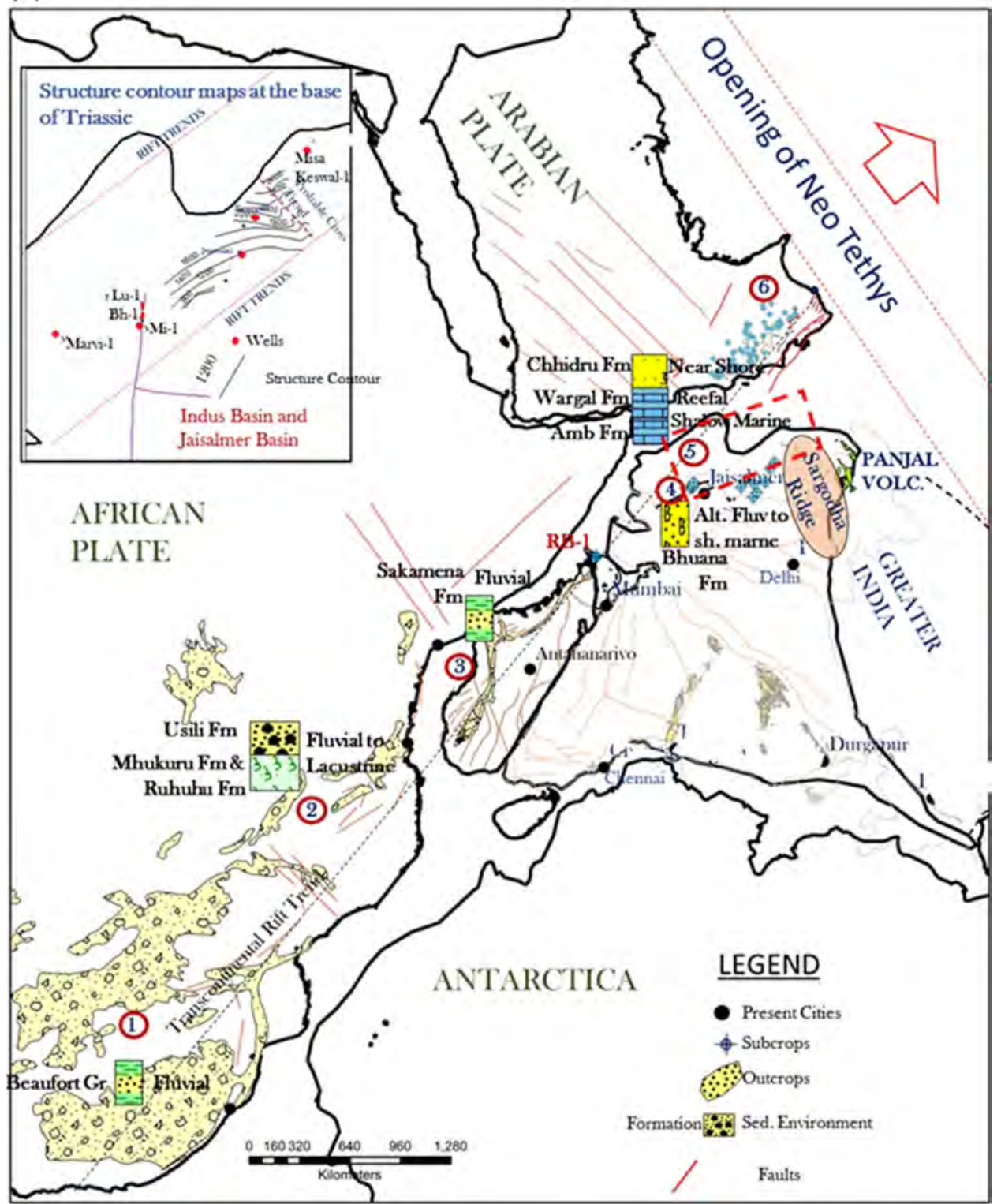

Figure 10. (Continued.)

southwards it is dominated by clastics with a predominant fluvial affinity (figure 11). The effect of the ridge as a barrier to transgression is evident from the palynostratigraphic studies (Lukose and Misra 1980 and Misra et al. 1996) in the pre-Lathi sediments in Jaisalmer basin. The studies indicate the upper part of the Permian sequence and basal part of Triassic as non-marine regressive sequence in contrast to the shallow marine sediments in basal Permian. Structure contour maps at the base of Triassic, of the Punjab platform in Indus Basin (Raza et al. 2008) rotated to their paleo-position in Triassic, display a parallelism in trends indicative of a rift controlled deposition in the area. However, geometry of the structure contours straightway suggests cross trends (figure 10b, inset). One of the effects of the development of the cross trends may be that the longitudinal drainages that developed in the earlier undifferentiated rift draining the entire basin may be restricted in this phase limiting their drainage area. This may lead to a lithological variation in the rift that is significantly different from the uniformity in sedimentation of Early Permian (figure 11).

During Middle Triassic to Early Jurassic, GIS based analysis of the different facies correlatives 
(c)

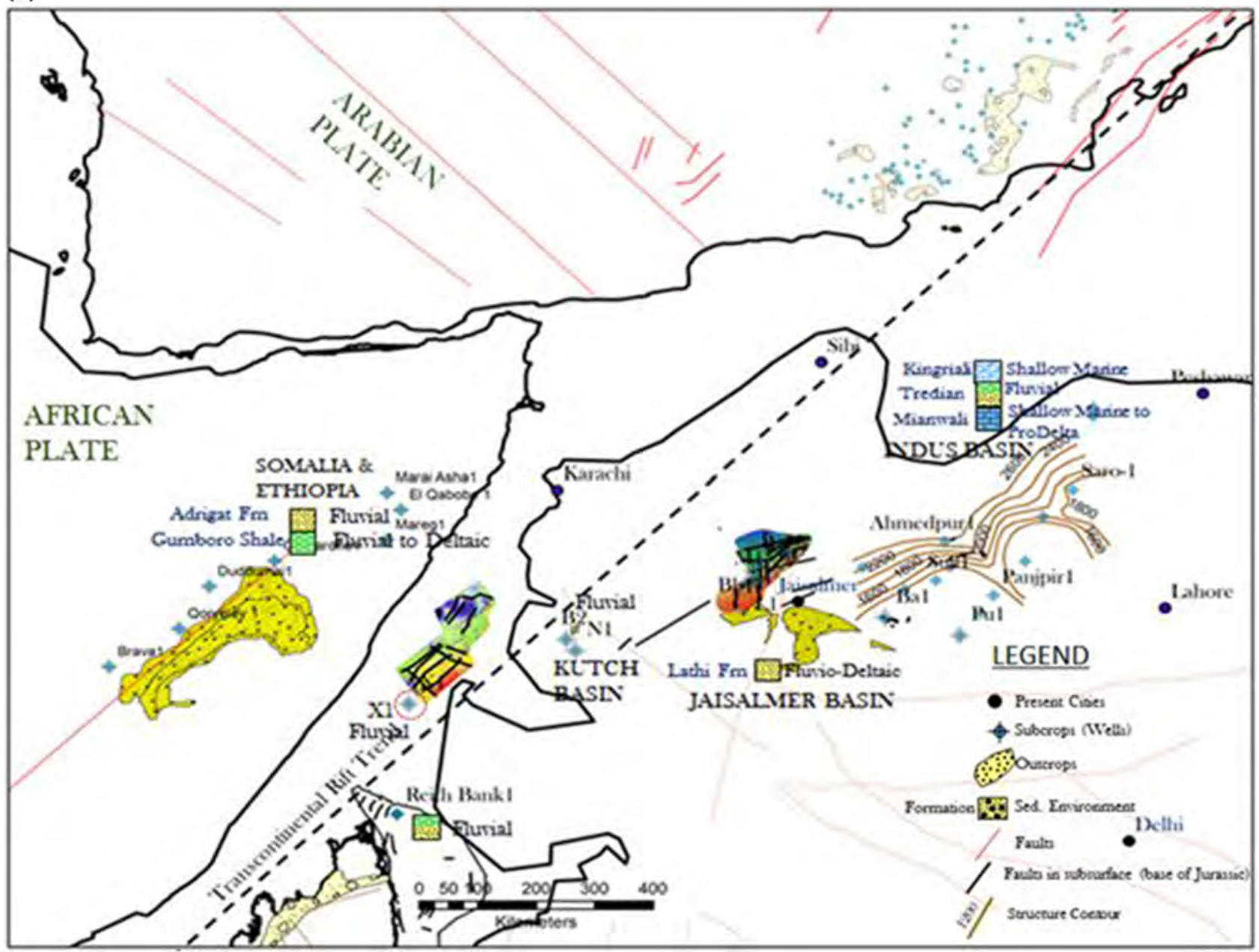

Figure 10. (Continued.)

indicate that dominant fluvial sedimentation in the transcontinental rift system may have continued without any major marine influences (figures 10c, 11). Palynostratigraphic studies (Saxena et al. 2016) record Late Triassic to Early Jurassic continental sediments in the well X-1 (figure 13a) in Saurashtra offshore with a good assemblage of spore-pollen. This closely resembles the assemblage from the two wells in B-2 and $\mathrm{N}-1$ in Kutch onland drilled by ONGC (figure 8b) in western India recorded by Koshal (1984). The recorded assemblage is also correlatable with the Late Triassic sediments of Zaluch Group in Kohat-Potwar area (Mukherjee 2015); Shumerwali Formation in Jaisalmer Basin and Stormberg Group, South Africa (Saxena et al. 2016) suggesting connectivity even in this phase. Another well Y1 (figure 13a) in Kutch offshore is also reported to show an Early to Middle Jurassic palyno-assemblage indicating a fluvial environment (Saxena et al. 2016). In the Kutch onland part, in Kaladonger Formation, though the lowest unit yields a nanofossil assemblage of Early Aalenian age, reworked nannofossils recovered from parts of it are indicative of a Lower Jurassic Pliensbachian-Toarcian age (figure 8b). Similarity has also been recorded between these reworked nannofossils recovered from Kutch basin and Late Pliensbachian age reworked nannofossils recovered from Masirah Island of Oman (Rai and Jain 2013). Structure and time contour maps of Late Triassic and Early Jurassic in Kutch and Saurashtra offshore, Jaisalmer basin, India and Punjab platform, Pakistan (Raza et al. 2008) in the Indian plate display structural development and subsurface morphology parallel to the transcontinental rift. Smaller faults mapped in seismic (Hasany et al. 2012; Raju et al. 2014) as 


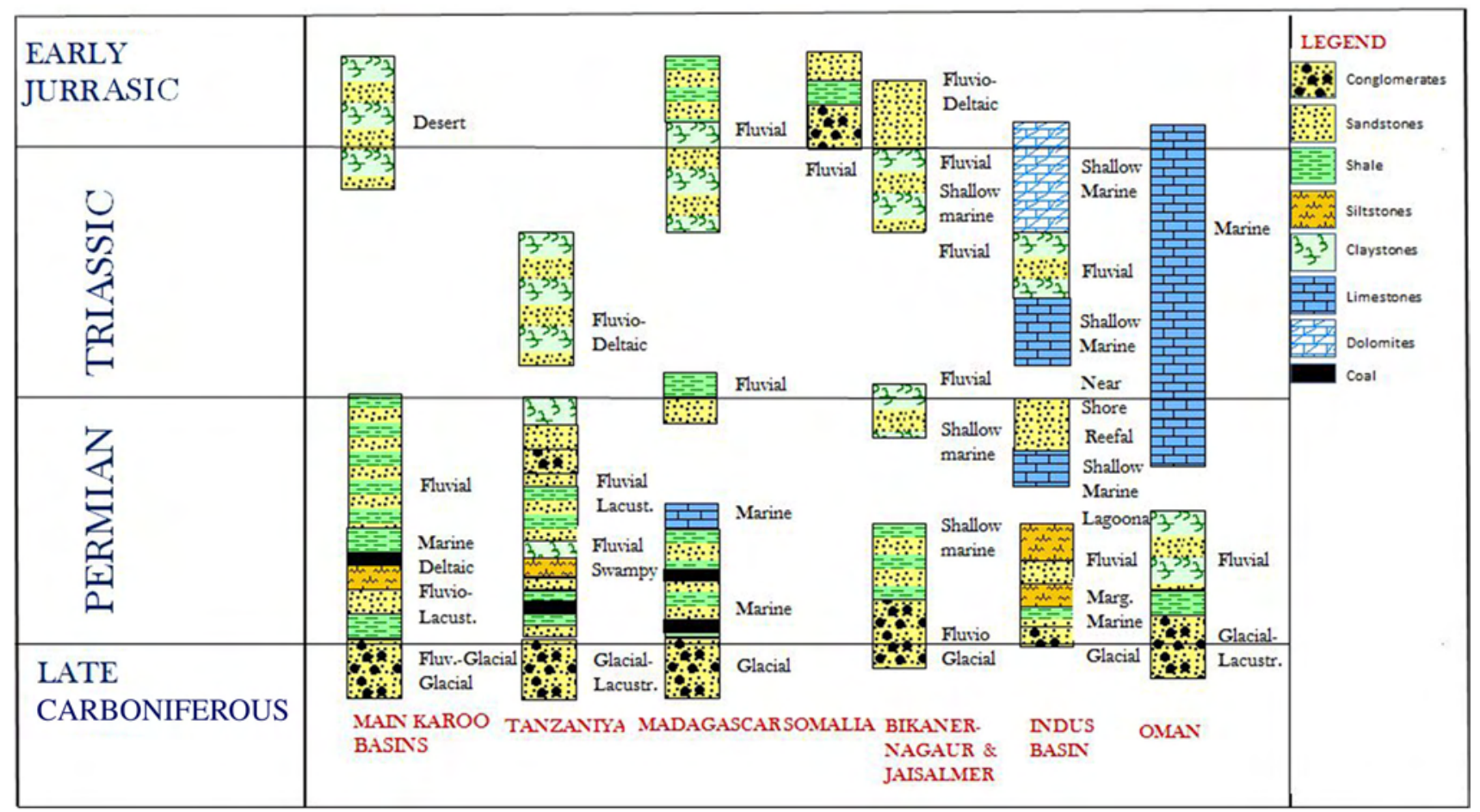

Figure 11. Sequence of sedimentary environments and broad lithologies in all basins discussed from south to north. Dominance of limestone and dolomite in the northern basins is observed whereas in the south, their correlative deposits are dominated by clastics resulting from fluvial sedimentation. Also the Late Carboniferous to Early Permian sediments show a uniformity in overall characters whereas lithological variation is significantly in the later sediments.

well as those on surface in these basins too conform these rift trends. This implies a rift related tectono-sedimentary setting continuing even in this phase. Grabens with small horsts in between had been mapped below Deccan Trap in the Jamnagar Dwarka area of the Saurashtra region by DSS studies with about $2500 \mathrm{~m}$ of sediments in them indicating such a setting (Pandey 2012).

The separation of the African plate from the Eastern Gondwana in Middle Jurassic probably marked the end of transcontinental rift setting with fluvial clastics getting replaced by marine carbonates. An overall lithological variation shows that the northern part of the rift depicts a dominant marine environment post-Permian whereas a dominantly continental environment dominated in the rest of the proposed rift from Jaisalmer-BikanerNagaur basins in the north to the main Karoo basins in the south (figure 11).

\section{Implications of the rift in hydrocarbon exploration}

A number of hydrocarbon producing sedimentary basins are found to overlie the assumed rift. In the northern part, Al-Khalata and Gharif formations in Oman act as a reservoir rocks for a number of oil fields (Bryant and Flint 2009). Similarly, in the Upper Indus Valley, Permian Tobra, Amb, and Wargal formations act as effective reservoir rocks for a number of producing fields like Adhi and Missa Keswal (Wandrey et al. 2004). In the southern part of the rift, heavy oil/tar sand had been discovered in Bemolanga and Tsimiroro in Isalo Formation in Madagascar and Ogaden Basin of Ethiopia is considered a proven petroleum basin producing from Calub and Adrigat sandstone (Boote and Matchette-Downes 2009). Oil seepages related to Adigrat sandstone in Somalia had also been observed (Southwestern Energy 2012). In Seychelles, Jurassic source rocks had been premised (Noskay 2012) based on geochemical studies on samples of well Reith Bank-1 (RB-1) attributing for its oil shows (figure 12). Migrated black oil is found in side-wall cores from the Karoo succession in wells drilled by Amoco with the same oil characteristics observed in numerous tar balls stranded around the many islands of the Seychelles archipelago.

All these imply the existence of a petroleum system within the rift system with the maturation aspect aided by heat related to the volcanics associated with rifting (Roberts et al. 2011). Also, 


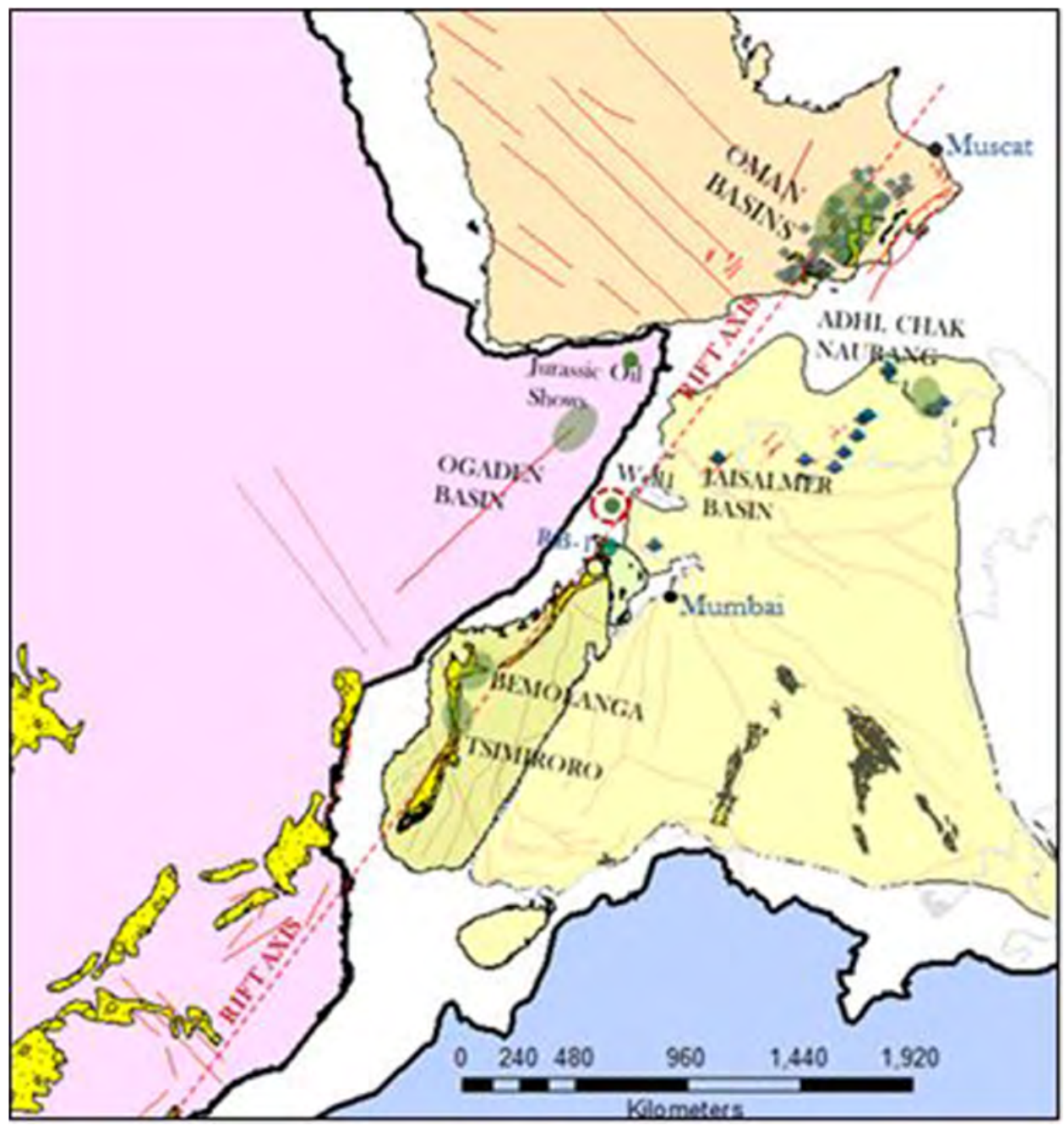

Figure 12. Hydrocarbon producing oil fields in different parts of the proposed rift with rift-related sediments. Well 1 in Saurashtra offshore may share a similar petroleum system making the area prospective. Green polygons and dots indicate oil fields and wells with hydrocarbon indications, respectively.

the shear heat/viscous dissipation (Mukherjee and Mulchrone 2013; Mulchrone and Mukherjee 2015, 2016; Mukherjee 2017) due to ductile/brittle deformation can have additional components.

In India, from the hydrocarbon point of view, the Jaisalmer and Bikaner-Nagaur Basin in Rajasthan are sedimentary basins occurring on the eastern flank of the proposed rift. However, the axis of the proposed transcontinental rift can be assumed to pass through present day offshore Kutch and Saurashtra (figure 13a) in an approximate N-S trend parallel to trend 4 of the Gondwana master basin in peninsular India (figure 1a). This passage of the rift-axis through offshore Kutch and Saurashtra implies maximum sedimentation in the area. Well 1 in offshore Saurashtra in proximity to the axis of the rift (figure 12) had produced oil from Lower Jurassic Sandstone (Mazumder et al.
2014) that is believed to be equivalent to Adrigat Sandstone (figure 12).

Additionally, hydrocarbon seepages could be identified in SAR images in the Kutch offshore and in Indus offshore area that could be classified to be of a high confidence level based on their repetitivity indicative of proximity to a conduit to a mature petroleum system (figure 13a; Dave et al. 2013). These seepages in the Kutch and Indus offshore area is found to be aligned along the proposed rift axis associated with the presence of deep seated grabens containing pre-Trappean sediment (figure 13b, c). These grabens may be a part of the proposed Gondwana rift. In this context, it may be mentioned that the Karoo sourced oil and the tar balls shares many similarities with the hydrocarbon provinces of Indus basins (Roberts et al. 2011). 
(a)

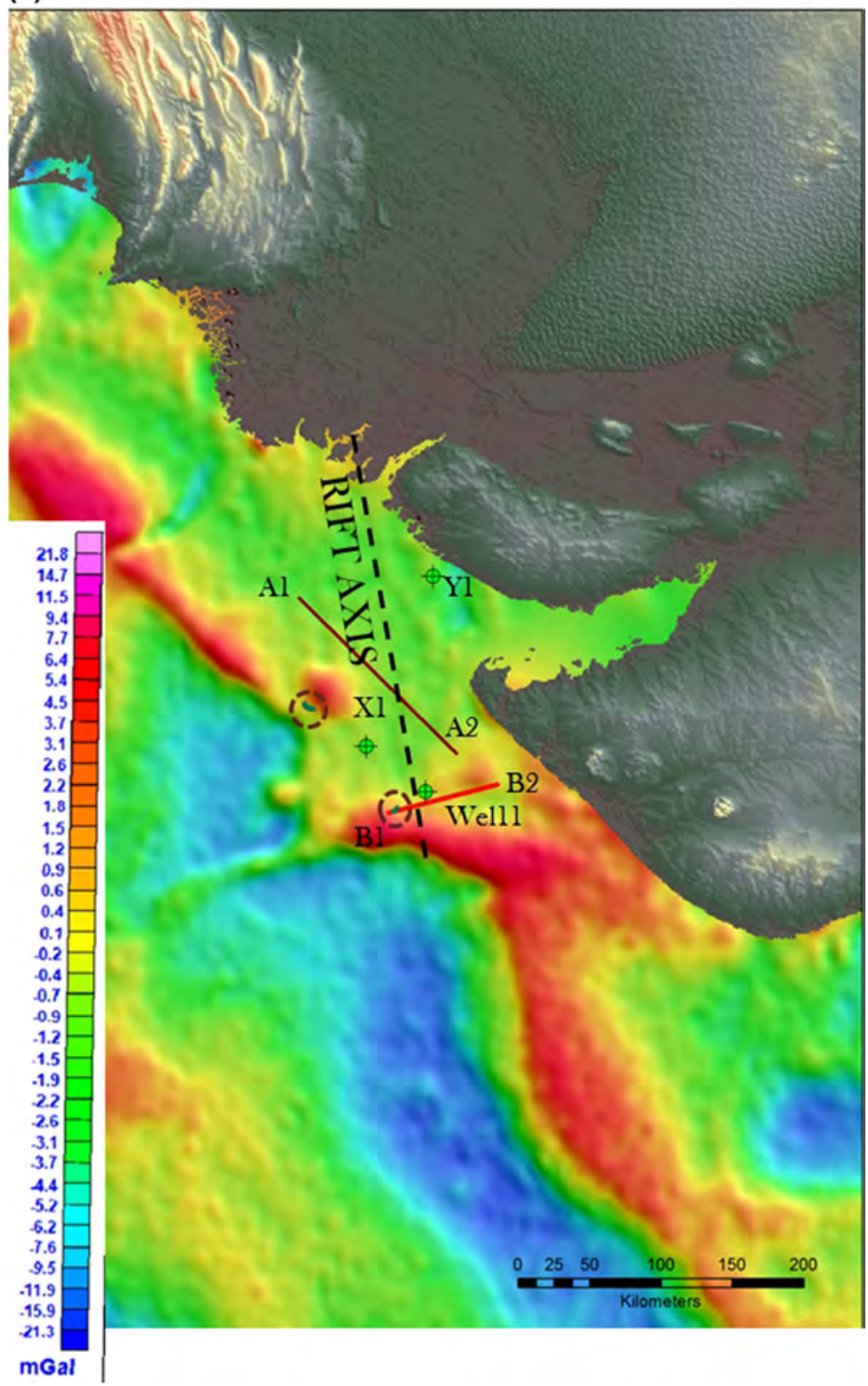

Figure 13. (a) Natural hydrocarbon seepages (encircled) of a high degree of confidence overlain on gravity data of Kutch and Saurashtra Offshore are found to be adjacent to the probable present day rift axis (black dotted line) and associated with deep seated Mesozoic grabens (figure 12c). (b and c) Show a longitudinal magneto-telluric profile (after Harinarayana 2008) along A1-A2 and a transverse seismic section along profile B1-B2 (after Dash et al. 2015) indicating the structural disposition of the Pre-Trappean rift sediments (Gondwanas?).

This indicates the apparent existence of rift related sedimentation with a well-developed and producible petroleum system in it. This might open up a new exploration frontier conceptualizing a Permo-Triassic basin in offshore Kutch and Saurashtra. This concept can be considered significant in the context that it is difficult to get a proper seismic image below the Deccan Traps in the area. Hence, such a concept based exploration might be helpful.

\section{Conclusions}

The above analysis puts forward a model of a Lower Gondwana rift extending from South Africa to Oman passing through Madagascar, Seychelles, Saurashtra, Jaisalmer, Bikaner-Nagaur of India and Indus Basin of Pakistan. Tectonically, this rift might be related to an aborted attempt of separation of Gondwana, with sedimentary records suggesting that it might have continued up to Early 
(b)

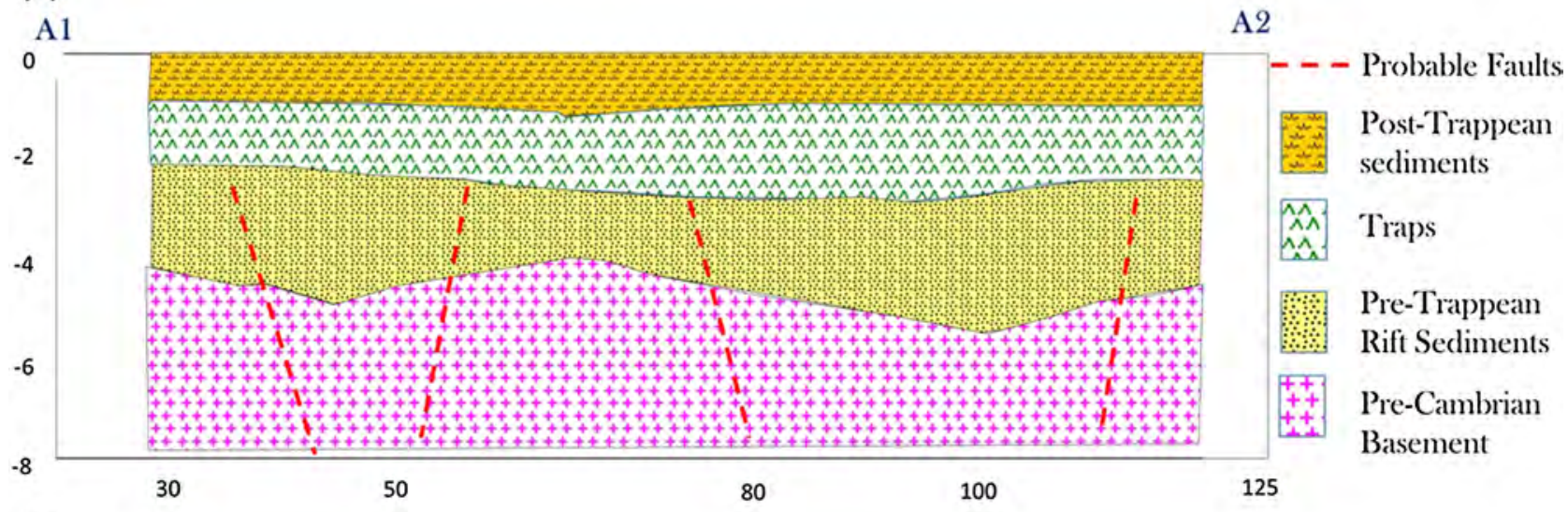

(c)

B1 B2

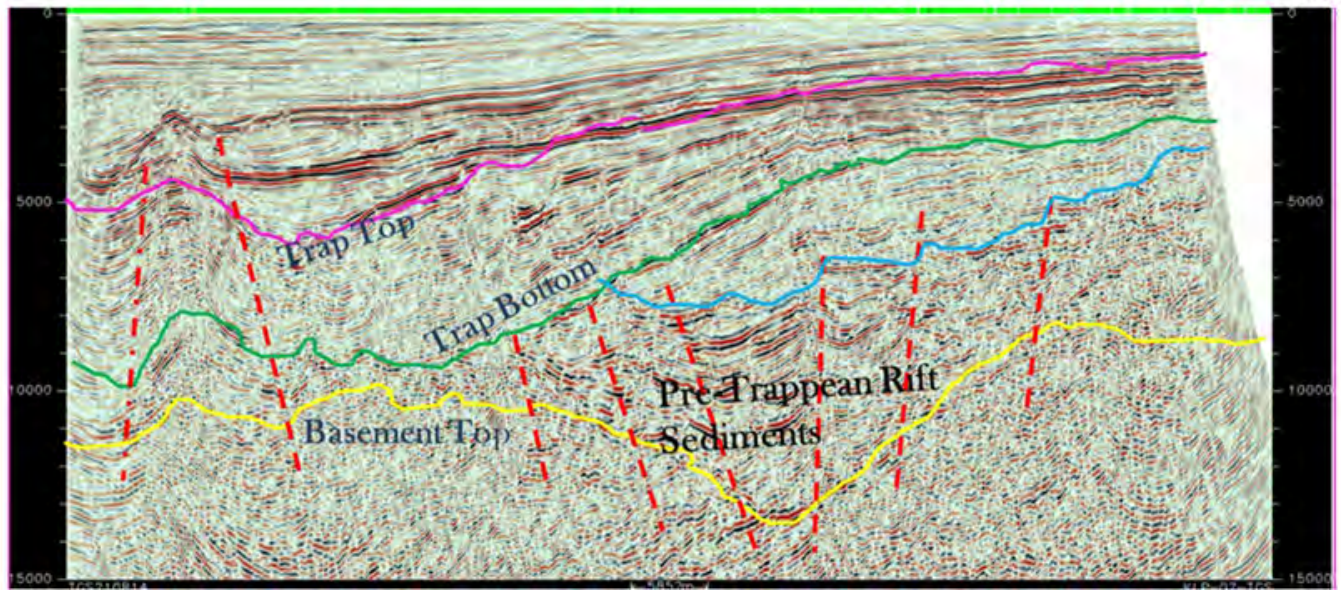

Figure 13. (Continued.)

Jurassic. Since the axis of the proposed rift passes through offshore Kutch and Saurashtra, probability of the existence of a thick Late Carboniferous to Early Jurassic sediments may be there in these areas below the Deccan Trap. These pre-Trappean sediments may have an operative petroleum system similar to the producing fields in areas that were earlier connected by this rift. Considering this presumption, this concept might be instrumental in making offshore Kutch and Saurashtra area more prospective in terms of hydrocarbon exploration.

Similar GIS-based analysis may also be taken up for the tectono-sedimentary reconstruction of other hydrocarbon producing basins to redefine their prospectivity in space and time. One such exercise may be the tectonic reconstruction of the Ediacaran-Cambrian sediments in India in Bikaner-Nagaur and Ganga Basin trying to connect them with stratigraphically equivalent and hydrocarbon bearing sediments in Oman in the Arabian plate.

\section{Acknowledgements}

The authors thank the Head of the Institute, KDMIPE and Director (Exploration), ONGC, Dehradun for their kind permission to publish this paper. The authors also acknowledge Dr Soumyajit Mukherjee for reviewing the manuscript.

\section{References}

Aadil N and Sohail G M 2011 Stratigraphic correlation and isopach maps of Punjab platform in middle Indus Basin, Pakistan; Proc. 2nd South Asian Geosci Conf. Exhibition, GEO India 2011, Greater Noida, New Delhi, India.

Aadil N, Qasim M and Hussain A 2013 Microfacies and diagenetic analysis of Amb Formation, western part of Central Salt Range, Pakistan; Pakistan J. Sci. 65(4) 503.

Abbasi I A, Hersi O S, Harthy A and Al-Rashdi I 2013 Lithofacies attributes, depositional system and diagenetic properties of the Permian Gharif Formation from Haushi-Huqf area, central Oman; Arab J . Geosci. 6(12) 4931-4945. 
Accordi G and Carbone F 2000 The Indian Ocean coast of Somalia; Mar. Pollut. Bull. 41 141-159.

Ahmed W 2008 Fossil fuel energy resources of Ethiopia; $B$. Chem. Soc. Ethiopia 22(1) 67-84.

Al-Aswad A A 1997 Stratigraphy, sedimentary environment and depositional evolution of the Khuff Formation in south-central Saudi Arabia; J. Petrol. Geol. 20(3) 307-326.

Asim S, Qureshi S N and Khan N 2014 Study of an uplift of Sargodha High by stratigraphical and structural interpretation of an east-west seismic profile in central Indus Basin, Pakistan; Int. J. Geosci. 5 1027-1036.

Behrensmeyer A K and Hill A P 1988 Fossils in the Making: Vertebrate Taphonomy and Paleoecology; University of Chicago Press, pp. 28-30.

Bhattacharya B, Bandyopadhyay S, Mahapatra S and Banerjee S 2012 Record of tide-wave influence on the coalbearing Permian Barakar Formation, Raniganj Basin, India; Sedim. Geol. 267-268 25-35.

Bhattacharya H N and Bhattacharya B 2015 Lithofacies architecture and paleogeography of late Paleozoic glaciomarine Talchir Formation, Raniganj Basin, India; J. Palaeogeogr. 4 269-283.

Boote D R D and Matchette-Downes C J 2009 Extinct and near extinct petroleum systems of the East African Coastal Basins; www.mdoil.co.uk/pdfs/HGSPESGB09_ East_Africa.pdf.

Bryant I D and Flint S S 2009 The Geological Modelling of Hydrocarbon Reservoirs and Outcrop Analogues; John Wiley \& Sons, pp. 135-136.

Casshyap S M 1979 Pattern of sedimentation in Gondwana Basins; Proc. Vol. Vth Int. Gondwana Symp., pp. $525-551$.

Casshyap S M and Tewari R C 1988 Depositional models and tectonic evolution of Gondwana basins of peninsular India; Palaeobotanist. 36 59-66.

Catuneanu O, Wopfner H, Eriksson P G, Cairncross B, Rubidge B S, Smith R M H and Hancox P J 2005 The Karoo basins of south-central Africa; J. Afr. Earth Sci. $43211-253$.

Chauvet F, Dumont T and Basile C 2009 Structures and timing of Permian rifting in the central Oman Mountains (Saih Hatat); Tectonophys. 475 563-574.

Chauvet F, Lapierre H, Bosch D, Guillot S, Mascle G, Vannay J C, Cotten J, Brunet P and Keller F 2008 Geochemistry of the Panjal Traps basalts (NW Himalaya): Records of the Pangea Permian break-up; B. Geol. Soc. France 179(4) 383-395.

Collins A S and Windley B F 2002 The tectonic evolution of central and northern Madagascar and its place in the final assembly of Gondwana; J. Geol. 110 325-339.

Dash P P, Prakash R, Gyanandra Saha P K, Joshi J and Rawat C P S 2015 Structure map near top of Jurassic, Kutch Saurashtra area, Western Offshore Group, KDMIPE, ONGC internal report, Unpublished.

Dave H D, Mazumder S, Pangtey K K S, Tep B and Mitra D S 2013 Delineation of prospective area in Palar offshore based on analysis of natural seepage model in Cauvery offshore; Proc. 10th Intl. Conf. Exposition, SPG-2013, Kochi, $\mathrm{P}-066$.

Delvaux D 1991 The Karoo to recent rifting in the western branch of the East-African rift system: A bibliographical synthesis; Project EGS, Royal Museum for Central Africa - Department of Geology and Mineralogy, B-3080 Tervuren (Belgium), pp. 63-83.

Delvaux D 2001 Karoo rifting in western Tanzania: Precursor of Gondwana break-up?; Contrib. Geol. Pal. Gondwana, pp. 111-125.

Ezaki Y 2006 Variations in the disappearance patterns of rugosan corals in Tethys and their implications for environments at the end of the Permian; In: Late Palaeozoic and Early Mesozoic Circum-Pacific Events and their Global Correlation (eds) Dickins J M, Zunyi Y and Hongfu Y, Cambridge University Press, pp. 126-133.

Ghazi S and Mountney N P 2010 Subsurface Lithofacies analysis of the fluvial Early Permian Warchha sandstone, Potwar Basin, Pakistan; J. Geol. Soc. India 76(5) 505-517.

Ghazi S, Mountney N P, Butt A A and Sharif S 2012 Stratigraphic and palaeo environmental framework of the Early Permian sequence in the Salt Range, Pakistan; J. Earth Syst. Sci. 121(5) 1239-1255.

Harinarayana T 2008 Marine seismic and marine magnetotellurics in Gulf of Kutch region, Gujarat, India; Project executed by NGRI, Hyderabad and NIO, Goa, Technical Report No: NGRI-2008-EXP-656.

Herbert C T and Compton J S 2007 Depositional environments of the Lower Permian Dwyka diamictite and Prince Albert shale inferred from the geochemistry of early diagenetic concretions, southwest Karoo Basin, South Africa; Sedim. Geol. 194 263-277.

Hasany S T, Aftab M and Siddiqui R A 2012 Refound exploration opportunities in Infracambrian and Cambrian sediments of Punjab platform, Pakistan; Search and Discovery, Article \#50576.

Heward A P and Penney R A 2014 Al Khlata glacial deposits in the Oman Mountains and their implications; Geol. Soc. London Spec. Publ. 392(1) 279-301.

Iqbal S, Jan I U and Hanif M 2013 The Mianwali and Tredian Formations: An example of the Triassic progradational deltaic system in the low-latitude western Salt Range, Pakistan; Arab. J. Sci. Eng. 39(7) 5489-5507.

Jan I U, Stephenson M H, Khan and Fazli R 2009 Palynostratigraphic correlation of the Sardhai Formation (Permian) of Pakistan; Rev. Palaeobot. Palyno. 158 (1-2) $72-82$.

Jan I U and Stephenson M 2011 Palynology and correlation of the Upper Pennsylvanian Tobra Formation from ZaluchNala, Salt Range, Pakistan; Palynology 35(2) 212-225.

Khan F R and Afzal J 2005 Comparative study of Brachiopods of Chhidru Formation from Zaluch and Nammal sections, Western Salt Range, Pakistan; Pakistan J. Hydrocarb. Res. 15 53-63.

Koshal V N 1984 Differentiation of Rhaetic sediments in the sub-surface of Kutch based on palynofossils; Petrol. Asia J. 7(1) 102-105.

Khan M A, Ahmed Riaz, Raza H A and Kemal A 1986 Geology of petroleum in Kohat-Potwar depression, Pakistan; AAPG Bull. 70(4) 396-414.

Kulkarni K G and Bokar V D 2014 Ichnofauna from the Harbans Bed of the Badhaura Formation (Sterlitmakian), Rajasthan, India; J. Earth Syst. Sci. 123(2) 421-432.

Kumar A 2010 Reworked Carboniferous palynomorphs in the Panna Formation (Paleocene-Early Eocene) of the 
Mumbai Offshore Basin, India: Possible role of megatsunami transport from the Arabian peninsula; Arab J. Sci. Eng. 35(1A) 167-185.

Kumpulainen R A, Uchman A, Woldehaimanot B, Kreuser T and Ghirmay S 2006 Trace fossil evidence from the Adigrat Sandstone for an Ordovician glaciation in Eritrea, NE Africa; J. African Earth Sci. 45 408-420.

Kusky T, Cordula R and El-Baz F 2005 Tertiary-Quaternary faulting and uplift in the northern Oman Hajar Mountains; J. Geol. Soc. 162 871-888.

Langhi L and Borel G D 2005 Influence of the Neotethys rifting on the development of the Dampier sub-basin (northwest shelf of Australia), highlighted by subsidence modelling; Tectonophys. 397 93-111.

Lapierre H, Sampera A, Bosch D, Maury R C, Be'chennecd F, Cotten J, Demante A, Brunetf P, Kellera F and Marcoux J 2004 The Tethyan plume: Geochemical diversity of Middle Permian basalts from the Oman; Lithos $\mathbf{7 4}$ $167-198$

Lukose N G and Misra C M 1980 Palynology of preLathi sediments (Permo-Triassic) of Shumarwali Talai structure, Jaisalmer, western Rajasthan, India; Proc. 4th Int. Palynological Conf., Lucknow, India (1976-77) 2 219-227.

Krueser T and Woldu G 2010 Formation of euxinic lakes during the deglaciation phase in the Early Permian of East Africa; In: Late Paleozoic Glacial Events and Postglacial Transgressions in Gondwana (eds) Lopez-Gamundi O R and Buatois L R, Geol. Soc. Am., Spec. Paper 468 $101-112$

Mazumder S, Tep B, Pangtey K K S and Mitra D S 2014 A Permo-Triassic reconstruction of western India and probable existence of a transcontinental rift system extending through western India and its implications in exploration in Kutch \& Saurashtra offshore - A GIS based approach, Petrotech 2014; Proc. 11th Int. Oil and Gas Conf. and Exhibition, India Expo Centre \& Mart, Greater Noida, New Delhi.

Mehrotra N C, Swamy S N and Rawat M S 2001 Reworked Carboniferous Palynofossils from Panna Formation, Bombay Offshore Basin: Clue to a hidden target for hydrocarbon exploration; J. Geol. Soc. India 57 239-248.

Metcalfe I 2011 Paleozoic and Mesozoic history of SE Asia, the SE Asian gateway: History and tectonics of the Australia-Asia Collision (eds) Robert Hall, Michael Andrew Cottam and Moyra Elizabeth Jane Wilson; Geol. Soc. London Spec. Publ. 355 7-35.

Misra A A and Mukherjee S 2015 Tectonic inheritance in continental rifts and passive margins; Springer briefs in Earth Sciences, ISBN 978-3-319-20576-2.

Misra A A, Bhattacharya G, Mukherjee S and Bose N 2014 Near N-S paleo-extension in the western Deccan region in India: Does it link strike-slip tectonics with IndiaSeychelles rifting?; Int. J. Earth Sci. 103 1645-1680.

Misra A A, Sinha N and Mukherjee S 2015 Repeat ridge jumps and microcontinent separation: Insights from NE Arabian Sea; Mar. Petrol. Geol. 59 406-428.

Mishra J S, Srivastava, B P and Jain S K 1961 Discovery of marine Permo-Carboniferous in western Rajasthan; Curr. Sci. 39 (7) 262-263.

Misra C M, Prasad B and Rawat R S 1996 Triassic Palynostratigraphy from the subsurface of the Jaisalmer Basin, western Rajasthan; Contrs. XV Indian Colloq. Micropal. Strat., Dehradun, pp. 591-600.

Mukherjee S 2015 A review on out-of-sequence deformation in the Himalaya; In: Tectonics of the Himalaya (eds) Mukherjee S, Carosi R, van der Beek P, Mukherjee B $\mathrm{K}$ and Robinson D, Geol. Soc. London Spec. Publ. 412 67-109.

Mukherjee S 2017 Shear heating by translational brittle reverse faulting along a single, sharp and straight fault plane; J. Earth Syst. Sci. 126 Article \#2.

Mukherjee S and Mulchrone K F 2013 Viscous dissipation pattern in incompressible Newtonian simple shear zones: An analytical model; Int. J. Earth Sci. 102 1165-1170.

Mulchrone K F and Mukherjee S 2015 Shear senses and viscous dissipation of layered ductile simple shear zones; Pure Appl. Geophys. 172 2635-2642.

Mulchrone K F and Mukherjee S 2016 Kinematics and shear heat pattern of ductile simple shear zones with slip boundary condition; Int. J. Earth Sci. 105 1015-1020.

Mukhopadhyay G, Mukhopadhyay S K, Roychowdhury M and Parui P K 2010 Stratigraphic correlation between different Gondwana basins of India; J. Geol. Soc. India $\mathbf{7 6}$ 251-266.

Naji A H L and Janardhana M R 2009 Structure of the crust beneath Qamar Basin, Eastern Yemen based on gravity and magnetic modelling; e-J. Earth Sci. India 2(3) 141-147.

Nyathi N 2014 Stratigraphy, sedimentary facies and diagenesis of the Ecca Group, Karoo Supergroup in the Eastern Cape, South Africa; M.Sc. Thesis, University of Fort Hare.

Noskay S 2012 The Seychelles, Petroleum System breakthrough studies; WHL Energy Presentation at Africa Oil Week, Cape Town.

Pandey U S 2012 Mapping the thickness of Deccan Trap flows in India from DSS studies and inferences about a hidden Mesozoic Basin in the Narmada-Tapti region; Proc. 9th Int. Conf. Exposition on Petroleum Geophysics, SPG Hyderabad, 469p.

Pangtey K K S, Mazumder S, Tep B and Mitra D S 2013 A GIS based plate tectonic reconstruction of western India during Neo-Proterozoic-Cambrian and its implication in hydrocarbon exploration in Ganga Basin; Proc. Nat. Conf. Earth Sci. India: Challenges and Emerging Trends (ESICET-2013), pp 65-66.

Prasad B, Asher R and Borgohain B 2010 Late Neoproterozoic (Ediacaran)-Early Paleozoic Cambrian acritarch from Marwar Suprgroup, Bikaner Nagaur basin, Rajasthan, India; J. Geol. Soc. India 75 415-431.

Pollastro R M 1999 Ghaba Salt Basin Province and Fahud Salt Basin Province, Oman - Geological Overview and Total Petroleum Systems, USGS Bull. 2167, https://pubs. usgs.gov/bul/b2167/b2167.pdf.

Petroseychelles 2013 The Seychelles increasing Initiatives; http://www.petroseychelles.com/index. $\mathrm{php} /$ geotechnical/tectonic-evolution.

Plummer P S and Belle E R 1995 Mesozoic tectonostratigraphic evolution of the Seychelles microcontinent; Sedim. Geol. 30A(5) 675-688.

Rai J and Jain S 2013 Pliensbachian nannofossils from Kachchh: Implications on the earliest Jurassic transgressive event on the western Indian margin; Zitteliana Series A53 105-120. 
Raju S V, Mathur N and Sarmah M K 2014 Geochemical characterization of Neoproterozoic heavy oil from Rajasthan, India: Implications for future exploration of hydrocarbons; Curr. Sci. 107(8) 1298-1305.

Raza H A, Ahmad W, Ali S M, Alam M M, S, Shafeeq M, Iqbal M, Noor I and Riaz N 2008 Hydrocarbon prospects of Punjab Platform Pakistan, with special reference to Bikaner-Nagaur Basin of India; Pakistan J. Hydrocarb. Res. 18 1-33.

Roberts G, Harmer C, Rutherford K and O'Brien C 2011 Deepwater West Coast India: Pre Basalt and other Mesozoic Plays; Proc. 2nd South Asian Geoscience Conf. and Exhibition, GEO India 2011, Greater Noida, New Delhi, India, Paper Id: 20549.

Saxena R K, Pundeer B S, Kothari P R and Asher R 2016 Palynostratigraphic studies of samples from new exploratory wells, Geology Group, ONGC Internal Report, unpublished.

Schandelmeier H, Bremer F and Holl H G 2004 Kinematic evolution of the Morondava rift basin of SW Madagascar from wrench tectonics to normal extension; J. Afr. Earth Sci. 38 321-330.

Scotese C R, Boucot A J and Mckerrow W S 1999 Gondwana paleogeography and paleoclimatology; J. Afr. Earth Sci. 28(1) 99-114.

Selley R C 1997 African Basin; Elsevier, pp. 213-216.

Semkiwa P, Kalkreuth W, Utting J, Mayagilo F, Mpanju F and Hagemann H 1998 The geology, petrology, palynology and geochemistry of Permian coal basins in Tanzania. 1. Namwele-Mkomolo, Muze and Galula coalfields; Int. J. Coal Geol. 36 63-110.

Shah S C and Mehrotra D K 1985 Early Permian foraminifera from the Bap Formation, Jodhpur, Rajasthan; Bull. Geol. Min. Met. Soc. India 52 311-318.

Shellnutt J G, Bhat G M, Wang K L, Brookfield M E, Dostal $\mathrm{J}$ and Jahn B 2012 Origin of the silicic volcanic rocks of the Early Permian Panjal Traps, Kashmir, India; Chem. Geol. 334 154-170.

Sidor C A, Angielczyk K D, Weide D M, Smith R M H, Nesbitt S J and Tsuji L A 2010 Tetrapod Fauna of the lowermost Usili Formation (Songea Group, Ruhuhu Basin) of southern Tanzania, with a new burnetiid record; DigitalCommons@University of Nebraska - Lincoln.

Singh N P 2006 Mesozoic lithostratigraphy of the Jaisalmer Basin, Rajasthan; J. Paleontol. Soc. India 51(2) 1-25.

Smith A G, Hurley A M and Briden J C 1981 Phanerozoic Paleocontinental World Maps; Cambridge University Press.

Smith R M H, Eriksson P G and Botha W J 1993 A review of the stratigraphy and sedimentary environments of the Karoo-aged basins of southern Africa; J. Afr. Earth Sci. (and the Middle East) 16(1-2) 143-169.

SouthWest Energy 2012 Geographical and Seismic Data Ogaden Basin; www.sw-oil-gas.com

Corresponding editor: N PURnACHANDRA RAO
Stampfli G M and Borel G D 2002 A plate tectonic model for the Paleozoic and Mesozoic constrained by dynamic plate boundaries and restored synthetic oceanic isochrones; Earth Planet. Sci. Lett. 196 17-33.

Tewari R C 1998 Channel sandstone bodies in fluvial Permian-Triassic Gondwana succession of peninsular India; J. Geol. Soc. India 51 747-754.

Torsvik T H and Cocks L R M 2013 Gondwana from top to base in space and time; Gondwana Res. 24 999-1030.

USGS 2012 Assessment of Undiscovered Oil and Gas Resources of Four East Africa Geologic Provinces; http:// pubs.usgs.gov/fs/2012/3039/contents/FS12-3039.pdf.

Uys J 2007 Lithostratigraphy, Depositional Environments and Sedimentology of the Permian Vryheid Formation (Karoo Supergroup), Arnot North, Witbank Coalfield, South Africa; M.Sc Thesis, University of Johannesburg.

Veevers J J and Tewari R C 1995 Gondwana master basin of peninsular India between Tethys and the interior of the Gondwanaland province of Pangea; Geol. Soc. Amer. Memoir 18 71-73.

Venkatachala B S and Rawat M S 1984 Palynofossils from the Bap Formation, Rajasthan, India; ONGC Bull. 21 61-68.

Wandrey C J, Law B E and Shah H A 2004 Patala-Nammal Composite Total Petroleum System, Kohat-Potwar Geologic Province, Pakistan; USGS Publication.

Wang D, Helmy M and Rawnsley K 2011 Glacial sedimentological interpretation from microresistivity images, $\mathrm{Al}$ Khlata Formation, Oman; Search and Discovery, Article \#50511.

Wescott W A and Diggens J N 1998 Depositional history and stratigraphical evolution of the Sakamena Group (Middle Karoo Supergroup) in the southern Morondava Basin, Madagascar; J. Afr. Earth Sci. 27(3) 461-479.

Wopfner H, Markwort S and Semkiwa P M 1991 Early diagenetic Laumontite in the Lower Triassic Manda Beds of the Ruhuhu Basin, southern Tanzania; J. Sedim. Petrol. 61(1) 65-71.

Wopfner H and Diekmann B 1996 The late Palaeozoic Idusi Formation of southwest Tanzania: A record of change from glacial to postglacial conditions; J. Afr. Earth Sci. 22(4) 575-595.

Wopfner H 2002 Tectonic and climatic events controlling deposition in Tanzanian Karoo basins; J. Afr. Earth Sci. 34 167-177.

Zaigham N A, Ahmad M and Hisam N 2012 Thar rift and its significance for hydrocarbons; Search and Discovery, Article \#20146.

Ziegler P A 2015 Post-Hercynian plate reorganization in the Tethys and Arctic-North Atlantic domains, TriassicJurassic Rifting: Continental Breakup and the Origin of the Atlantic Ocean and Passive Margins (ed.) Manspeizer W, Elsevier, pp. 711-756. 